\title{
The last two millennia: climate, ocean circulation and palaeoproductivity inferred from planktic foraminifera, south-western Svalbard margin
}

\author{
Katarzyna Zamelczyk, ${ }^{1}$ Tine L. Rasmussen, ${ }^{1}$ Markus Raitzsch ${ }^{2,3}$ \& Melissa Chierici ${ }^{4}$ \\ ${ }^{1}$ Centre for Arctic Gas Hydrate, Environment and Climate, Department of Geoscience, UiT-The Arctic University of Norway, Tromsø, Norway; \\ ${ }^{2}$ MARUM - Center for Marine Environmental Sciences, University of Bremen, Bremen, Germany; \\ ${ }^{3}$ Alfred Wegener Institute Helmholtz Centre for Polar and Marine Research, Bremerhaven, Germany; \\ ${ }^{4}$ Institute of Marine Research, Fram Centre, Tromsø, Norway
}

\begin{abstract}
We reconstruct climate and changes in water-mass properties in relation to variations in palaeoproductivity at the south-western Svalbard margin throughout the last 2000 years. Environmental conditions in subsurface (ca. 250-75 m) and near-surface to surface water $(75-0 \mathrm{~m})$ were studied on the basis of the distribution patterns and fluxes of planktic foraminiferal faunas. Stable isotopes in three different species were measured, and $\mathrm{Mg} / \mathrm{Ca}$ - and transfer function-based sea-surface temperatures were calculated. The mean shell weights of planktic foraminiferal species were used to assess changes in calcium carbonate preservation. Modern total planktic foraminiferal distribution patterns from plankton tows and the water column carbonate chemistry were investigated for comparison with the palaeo-data. The results show warm sea-surface conditions and moderate to high surface productivity at ca. 21-400 AD, ca. 900-1400 AD and from about $1850 \mathrm{AD}$ until present, which may be local expressions of the European climatic events known as the Roman Warm Period, the Medieval Climate Anomaly and the Recent Warming. In general, cold near-sea-surface conditions and very low to moderate average productivity occurred at about 400-900 AD and ca. 1400-1850 AD, the latter probably the local expression of the Little Ice Age. The highest and most variable planktic productivity occurred at ca. 1300-1500 AD, ca. 1750-1860 AD and during the last 50 years or so. These periods are linked to the general amelioration of conditions from years with a dense sea-ice cover to years with a rapidly fluctuating summer sea-ice margin.
\end{abstract}

To access the supplementary material, please visit the article landing page

\section{Keywords}

Late Holocene; Fram Strait; Arctic hydrography; sea-surface/subsurface palaeoenvironments; Storfjorden Fan

\section{Correspondence}

Katarzyna Zamelczyk, Centre for Arctic Gas Hydrate, Environment and Climate, Department of Geoscience, UiT-The Arctic University of Norway, Dramsveien 201, NO-9037 Troms $\varnothing$, Norway. E-mail: katarzyna. zamelczyk@uit.no
Abbreviations
AD: anno Domini
AMS: accelerator mass spectrometry
$\mathrm{A}_{\mathrm{T}}$ : total alkalinity
$\mathrm{BC}$ : before Christ
$C_{C}$ : total dissolved inorganic carbon
CTD: conductivity-temperature-depth instrument
IRD: ice-rafted debris
$\mathrm{Ky}^{-1}$ : per thousand years
SMOW: standard mean ocean water
SR: sedimentation rate
SST: sea-surface temperature
TC: total carbon
TOC: total organic carbon
UIT: UiT-The Arctic University of Norway, Tromsø
VINDTA: Versatile Instrument for the Determination of Total Inorganic Carbon and Titration Alkalinity (laboratory alkalinity titration system)
V-PDB: Vienna Pee Dee Belemnite (reference standard for carbon isotopes)
V-SMOW: Vienna Standard Mean Ocean Water WSC: West Spitsbergen Current

\section{Introduction}

Warm and saline Atlantic surface water transported to the Nordic seas undergoes cooling in winter during northward flow in the Norwegian Current. In some areas, such as the Greenland Sea, the dense surface water subsequently sinks to form cold deep water. Further north the warm Atlantic Water meets the cold water flowing southward from the Arctic Ocean. The two water masses form a front, referred to as the Polar Front (Rudels 1996; Rudels et al. 2000). The mixing of these two water masses introduces nutrients into the euphotic zone, generating the most productive surface waters of the Nordic seas and Fram Strait (Smith et al. 1987; Smith \& Sakshaug 1990). 
The flow of warm Atlantic Water via the WSC into the Arctic Ocean is considered a major controlling factor of climate and the location of the sea-ice margin and therefore of the surface water productivity in Fram Strait (e.g., Walczowski \& Piechura 2011; Beszczynska-Möller et al. 2012; Walczowski et al. 2017). Numerous studies have examined changes in circulation, productivity and properties of the Atlantic Water in the Nordic seas during the Holocene and the past glacial period (e.g., Rasmussen et al. 2003; Ellingsen et al. 2008; Müller et al. 2012; Pathirana et al. 2015; Hoff et al. 2016; Berben et al. 2017). As only a few high-resolution studies in the Arctic areas have been undertaken (Wollenburg et al. 2004; Majewski et al. 2009; Spielhagen et al. 2011; Werner et al. 2011; Pawłowska et al. 2016), knowledge regarding the natural variability in ocean surface conditions and surface productivity for the last two millennia before the last 150 years is still scarce. Variations in the inflow of warm Atlantic Water, its mixing with cold Polar Water and the resulting changes in productivity were probably controlled by natural climate anomalies before human impact became a dominant factor (e.g., Spielhagen et al. 2011; Pathirana et al. 2015; Pawłowska et al. 2016).

The purpose of the present study is to reconstruct the properties of the upper approximately $250 \mathrm{~m}$ of the water column in Fram Strait, focusing on the south-western Svalbard margin $\left(76^{\circ} \mathrm{N}\right)$ and the development over historical times (the past 2000 years) to get a better understanding of the properties of the Atlantic Water, its interactions with polar surface water, meltwater and associated productivity changes in relation to climate change. Box core HH12-1206BC from Storfjorden Fan, south-west of Svalbard, was taken in the Atlantic Water domain of Fram Strait and close to the present Arctic Front, where Atlantic and Polar Water meet and mix (Fig. 1). This study is based on the distribution patterns of planktic foraminifera, the concentration and flux of the total foraminiferal fauna and individual species used as indications of productivity change, along with reconstructions of absolute SSTs ( $\mathrm{Mg} / \mathrm{Ca}$ ratios and transfer functions). Furthermore, based on the main depth habitats of the planktic foraminiferal species Neogloboquadrina pachyderma and Turborotalita quinqueloba, we use the difference in the $\delta^{18} \mathrm{O}$ values between $N$. pachyderma and T. quinqueloba $\left(\Delta \delta^{18} \mathrm{O}_{\mathrm{Np}-\mathrm{Tq}}\right)$ as a proxy for increased/decreased presence of Atlantic Water (sensu Moffa-Sánchez \& Hall 2017). To investigate the reliability of our palaeo-reconstructions, we use dissolution proxies and other geochemical and sedimentological data to assess changes in preservation of the specimens. Dissolution may severely influence the faunal composition (Berger 1970; Le \& Thunell 1996), Mg/Ca ratios (e.g., Nürnberg 1995), temperature estimates based on transfer functions (e.g., Imbrie \& Kipp 1971) and faunal concentrations (Berger 1970; Thunell \& Honjo 1981; Vincent \& Berger 1981; Peterson \& Prell 1985; Conan et al. 2002; Petró et al. 2018). To better compare the past with modern surface and productivity conditions, we also analysed living planktic foraminiferal faunas from plankton tows and the water carbonate chemistry. The results are compared to studies from other areas of the Svalbard margin and the North Atlantic and Nordic seas to study the nature of climate, ocean circulation and palaeoproductivity changes in the Arctic on a regional basis.

\section{Environmental setting}

The Nordic seas are characterized by three main surface water masses. In the eastern part, the Atlantic surface water of the North Atlantic Current flows northwards. This flow carries heat and salt into the Arctic region and helps maintain large ice-free areas year-round and keeps the south-western Svalbard climate significantly warmer in wintertime than at comparable latitudes elsewhere in the world (e.g., Isachsen et al. 2007; Dickson et al. 2008; Rhines et al. 2008). The western part of the Nordic seas is affected by the East Greenland Current, which carries cold Polar Water and sea ice from the Arctic Ocean southward. The central part is occupied by Arctic surface water generated from mixing of the Atlantic and Polar waters (Hop et al. 2006). The cooling of the Atlantic Water generates cold deep waters, which overflow the Greenland-Scotland Ridge as a cold and dense bottom current. The overflow waters become the main contributor to North Atlantic Deep Water, which represents a vital component in the control of the global thermohaline circulation and climate (Van Aken 2006).

On a regional scale, the hydrographic regime at Storfjorden Fan is determined by changes in volume and speed of the temperate and saline Atlantic Water $(S>35$; $T>3.0^{\circ} \mathrm{C}$ ) transported by the West Spitsbergen Current, the northern extension of the Atlantic Current and the cooler and less saline Arctic surface water $(S>34.3-34.8$; $T<0{ }^{\circ} \mathrm{C}$ ) conveyed by the East Spitsbergen Current (Fig. 1; Loeng 1991). A mixture of Arctic Water and sea ice from the northern Barents Sea and/or produced in Storfjorden is carried northward by the CC, originating from the East Spitsbergen Current (Fig. 1). The density gradients between the two water masses generate the Arctic Front that defines the maximum sea-ice extent in winter (Vinje 1977; Loeng 1991). During the spring/summer period, the sea-ice edge usually retreats northwards on the account of melting. Atlantic Water inflow and seaice melting often generate the Marginal Ice Zone, with a stratified and nutrient-rich euphotic zone and high primary productivity at the surface (Smith et al. 1987; Smith \& Sakshaug 1990; Sakshaug \& Slagstad 1992; Sakshaug 1997; Wassmann et al. 1999; Owrid et al. 2000; Reigstad 


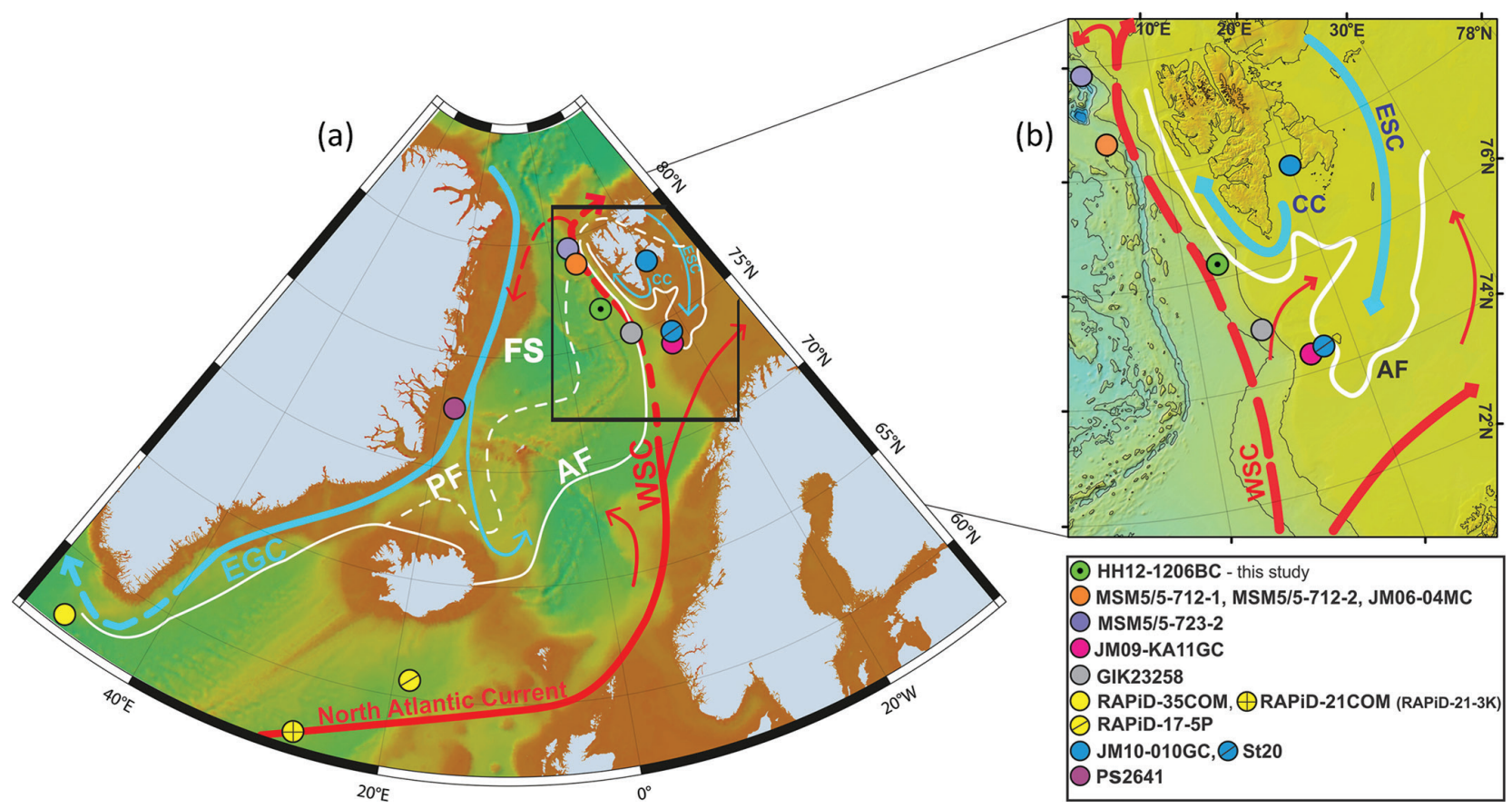

Fig. 1 (a) Schematic map of northern North Atlantic, Fram Strait and western Barents Sea showing bathymetry, present-day major surface currents and average position of Polar and Arctic fronts. (b) Close-up of western Svalbard margin, north-western Barents Sea. Solid and dashed lines indicate surface and subsurface currents, respectively. Location of core HH12-1206BC (green circle) is indicated together with published records discussed in the text (listed in legend and Supplementary Table S1). FS: Fram Strait; WSC: West Spitsbergen Current; CC: Coastal Current; ESC: East Spitsbergen Current; EGC: East Greenland Current; AF: Arctic Front; PF: Polar Front.

et al. 2002; Tremblay \& Gagon 2009). During years with strong and cold winds from the north-east, a large volume of brine is produced in the Storfjorden polynya (Skogseth et al. 2008). Storfjorden Fan can be influenced by these cold and corrosive brines as they descend the slope to the deep waters (Skogseth et al. 2008; Rasmussen et al. 2014).

\section{Material and methods}

\section{Present-day water-mass properties and living planktic foraminifera from plankton tows}

Water column temperature and salinity profiles at the Storfjorden Fan core site (see later) were measured via an SBE 911 plus CTD rosette (Seabird Scientific) equipped with Niskin bottles. CTD measurements took place aboard the RV Helmer Hanssen on successive cruises in October 2012, July 2014 and April 2015 (Fig. 2).

In April 2015, water samples were collected in the water column for carbonate chemistry (Fig. la). $\mathrm{C}_{\mathrm{T}}$ and $\mathrm{A}_{\mathrm{T}}$ were measured at the Institute of Marine Research, Tromsø, Norway. $\mathrm{C}_{\mathrm{T}}$ was determined by using coulometric titration on a VINDTA system and $\mathrm{A}_{\mathrm{T}}$ by using potentiometric titration with weak $\mathrm{HCl}$ on a VINDTA system (Marianda, Germany). The analytical methods and sampling procedures are described in detail in Dickson et al. (2007). The precision of $A_{T}$ and $C_{T}$ was determined using certified reference material supplied by A. Dickson (San Diego, USA) by applying a correction factor to the measured certified reference material value showing an uncertainty of $\pm 1 \mu$ mol kg-1 for both $\mathrm{A}_{\mathrm{T}}$ and for $\mathrm{C}_{\mathrm{T}}$ measurements. The data of $\mathrm{C}_{\mathrm{T}^{\prime}}, \mathrm{A}_{\mathrm{T}}$ and salinity, temperature and depth for each sample were used in a $\mathrm{CO}_{2}$-chemical speciation model ( $\mathrm{CO}_{2}$ SYS program; Pierrot et al. 2006) to calculate the calcium carbonate saturation state $\left(\Omega_{\mathrm{Ca}}\right)$, $\mathrm{pH}$ and the carbonate-ion concentration $\left[\mathrm{CO}_{3}{ }^{2-}\right]$. The calculations were performed on a total hydrogen ion scale using the hydrogen sulphate $\left[\mathrm{HSO}_{4}^{-}\right]$dissociation constant of Dickson (1990). We applied the carbonate system dissolution constants from Mehrbach et al. (1973), refit by Dickson \& Millero (1987). The concentration of calcium $\left[\mathrm{Ca}^{2+}\right]$ is assumed to be proportional to the salinity according to the equation $10.28 \times \mathrm{S} / 35 \mu \mathrm{mol} \mathrm{\textrm {kg } ^ { - 1 }}$ (Mucci 1983). The thermodynamic solubility product constants for calcite $\left(\mathrm{K}_{\mathrm{sp}}\right)$ are from Mucci (1983). The $\Omega_{\mathrm{Ca}}$ value is expressed by the product of concentrations of calcium ions $\left[\mathrm{Ca}^{2+}\right]$ and $\left[\mathrm{CO}_{3}{ }^{2-}\right]$ in seawater divided by the solubility product constant $\left(\mathrm{K}_{\mathrm{sp}}\right)$ at a given temperature, salinity and pressure. When $\Omega>1, \mathrm{CaCO}_{3}$ will be kept in solid state, and when $\Omega<1, \mathrm{CaCO}_{3}$ will tend to dissolve. 
(a) $\left[\mathrm{CO}_{3}{ }^{2-}\right]\left(\mu \mathrm{mol} \mathrm{kg}^{-1}\right)$

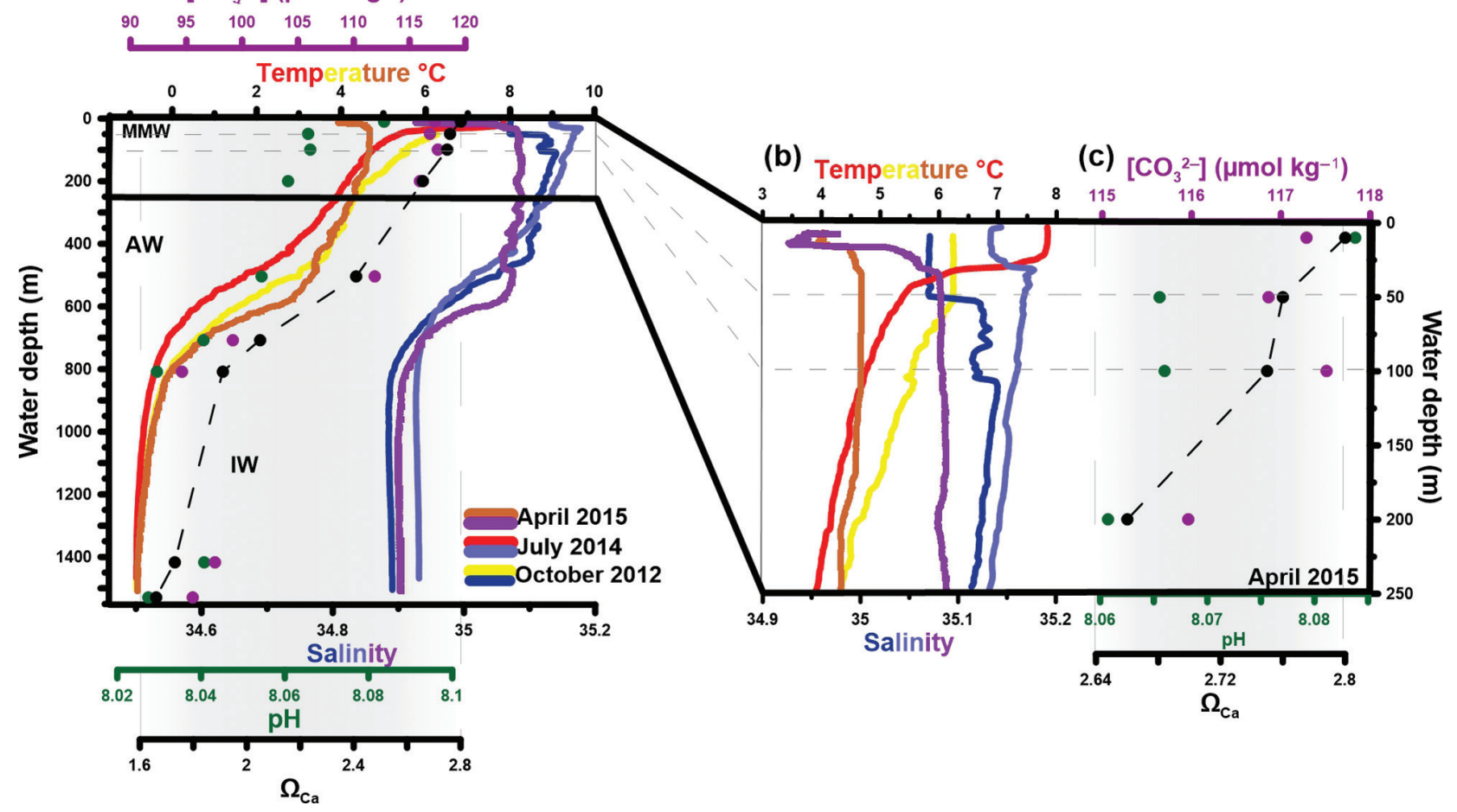

Fig. 2 (a) CTD profile showing water mass distribution of the water column in October 2012, July 2014 and April 2015 at site HH12-1206BC. Carbonate chemistry parameters ( $\mathrm{pH}, \mathrm{CO}_{3}{ }^{2-}, \Omega_{\mathrm{Ca}}$ ) for April 2015 are also shown. Range of $\Omega_{\mathrm{Ca}}$ in the water column is indicated by grey bars. (b) Close-up of CTD data in upper $250 \mathrm{~m}$. (c) Carbonate ion concentration [ $\left.\mathrm{CO}_{3}{ }^{2}\right]$, $\mathrm{pH}$ and calcium carbonate saturation state $\left(\Omega_{\mathrm{Ca}}\right)$ in upper $250 \mathrm{~m}$ in April 2015. MMW, mixed meltwater; AW, Atlantic Water; IW, intermediate water.

Living planktic foraminifera were collected using a WP (Working Party) 2 plankton tow with 90- $\mathrm{mm}$ meshsize net and $0.255 \mathrm{~m}^{2}$ opening. The plankton tows were deployed immediately after the CTD casts in October 2012 and July 2014 at the core site. In 2012, vertical sampling intervals were $0-50$ and $50-200 \mathrm{~m}$, while in 2014 , the intervals were 0-50, 50-100 and 100-200 m. Concentrations of the foraminifera (number specimens $\mathrm{m}^{-3}$ ) were calculated based on tow speed and water volume. Towing speed was about $0.5 \mathrm{~m} \mathrm{~s}^{-1}$ and the volume of filtered water was calculated by multiplying the aperture area by depth towed following the general formula: $V=\pi r^{2} \times L$, where $V=$ volume $\left(\mathrm{m}^{3}\right)$ of seawater, $\pi=3.1415, r^{2}=$ radius of net opening squared $\left(\mathrm{m}^{2}\right)$ and $L=$ length of towing $(\mathrm{m})$. After retrieval, the samples were sieved over sieves of mesh sizes 1000 and $63 \mu \mathrm{m}$ in the onboard laboratory and fixed with $98 \%$ ethanol buffered with disodium hydrogen phosphate to prevent dissolution (size fraction $>63 \mu \mathrm{m}$ only). The samples were stained with Rose Bengal $\left(1.0 \mathrm{~g} \mathrm{l}^{-1}\right)$ in order to differentiate between "living" (shell containing cytoplasm) and "dead/transported" specimens (no cytoplasm present; Lutze \& Altenbach 1991). Samples were kept cool until onshore analysis was performed in the laboratory at UiT. Only living specimens were considered.

\section{Palaeo-data from sediment core HH12-1206BC}

A giant box core $(50 \times 50 \times 50 \mathrm{~cm}$ with a volume of 125 L) was used to sample sediment from Storfjorden Fan from 1520-m water depth during a cruise with RV Helmer Hanssen to the Fram Strait in October $2012\left(76^{\circ} 24^{\prime} \mathrm{N}\right.$; $012^{\circ} 58^{\prime} \mathrm{E}$; Fig. la). The sediment-water interface was well preserved and undisturbed. A plastic tube of inner diameter $10 \mathrm{~cm}$ was pushed into the sediment for subsampling. The $30.5 \mathrm{~cm}$ long sediment core labelled HH12-1206BC was sampled in $0.5 \mathrm{~cm}$ thick slices in the laboratory at UiT. Subsequently, all samples were weighed, freezedried and weighed again, and the water content (\%) was calculated. The dry samples were wet-sieved through mesh-sizes $1 \mathrm{~mm}, 500 \mu \mathrm{m}, 100 \mu \mathrm{m}$ and $63 \mu \mathrm{m}$ following the preparation methods of Feyling-Hanssen et al. (1971) and Knudsen (1998). The residues were dried at room temperature and weighed.

Grain size distribution was calculated as the weight percentage of each grain-size fraction relative to total dry weight of the sample. IRD was counted in the 500-1000 $\mu \mathrm{m}$ and $>1000 \mu \mathrm{m}$ size-fractions and concentrations calculated as number of IRD grains per gram dry weight sediment. 
TC and TOC were measured in the intervals of $1-2 \mathrm{~cm}$ in powdered bulk samples using a Leco CS-200 induction furnace instrument. The weight percentages (wt \%) of TC and TOC were calculated. The $\mathrm{CaCO}_{3}$ content (wt\%) was calculated using the following equation: $\mathrm{CaCO}_{3}=$ $($ TC-TOC) $\times 8.33$ (Espitalié et al. 1977) .

Planktic foraminiferal specimens (>300) from the size-fraction 100-500 $\mu \mathrm{m}$ were picked from all the 0.5 -cm-thick samples, 62 in total. The majority of samples were split, and specimens were counted and identified to species level using a binocular microscope (Leica MZ16). The concentration was calculated as number of foraminifera per gram dry-weight sediment, and the flux of planktic foraminiferal specimens (number of specimens $\mathrm{cm}^{-2} \mathrm{Ky}^{-1}$ ) was calculated using the methods described by Ehrmann \& Thiede (1985).

Transfer functions, based on the census data of the planktic foraminiferal species, were used to reconstruct SSTs at 10-m water depth and to compare to $\mathrm{Mg}$ / Ca-based subsurface temperatures (see later). The statistical method compares modern oceanographic data (here summer SST) with the species composition of the planktic foraminiferal faunas in the $>100-\mu \mathrm{m}$ size-fraction from surface sediments collected in the Nordic seas (Husum $\&$ Hald 2012). The data were processed using the data analysis programme C2 version 1.3 (Juggins 2010). The maximum estimate had the lowest root mean square error of prediction, indicative for the most predictive transfer function model (Telford \& Birks 2005). This is confirmed as the maximum-likelihood-calculated SSTs are close to the modern water temperature ranges of the core site and follow the actual fluctuations in species composition of the planktic foraminiferal faunas.

Shell weights of ca. 20-30 pristine and well-preserved tests of planktic foraminiferal species $N$. pachyderma and T. quinqueloba from two narrow size ranges of 100-125 $\mu \mathrm{m}$ and 150-180 $\mu \mathrm{m}$ were measured using a Sartorius microbalance (model M2P, $0.1 \mu \mathrm{g}$ sensitivity). Specimens with sediment fill or visually detectable secondary calcite crust were omitted. Mean shell weights were calculated by dividing the total weight of the individuals by the number of total shells within each size range. Because of the low abundance of T. quinqueloba, 16 samples from the 100-125- $\mu \mathrm{m}$ size-fraction and 15 samples from the 150-180- $\mu \mathrm{m}$ size-fraction contained less than 10 individuals. All measurements were repeated three times.

Shell fragments were counted in the >100- $\mu \mathrm{m}$ size-fraction along with the counts of the whole planktic specimens as an indication for the general preservation state of specimens and species (Berger 1970; Berger et al. 1982). The \%fragmentation was calculated relative to the total number of planktic foraminifera per gram and the total number of fragments per gram in a sample.
Activity profiles of ${ }^{210} \mathrm{~Pb}$ and ${ }^{137} \mathrm{Cs}$ were analysed in the top 12 samples (upper $6.5 \mathrm{~cm}$ ) in order to determine the modern SR, assess the recovery of core top sediments and establish the age of the youngest sediments. Freeze-dried and homogenized samples were analysed at the Centre d'Études Nordiques at the Université Laval (Canada) using a high-resolution germanium diode gamma detector and multichannel analyser gamma counter. Prior to analysis, the samples were put into plastic vials to rest for at least three weeks to attain the secular equilibrium. The linear apparent SR was calculated from the decrease of excess ${ }^{210} \mathrm{~Pb}$ activities with sediment depth following McKee et al. (1983). Excess ${ }^{210} \mathrm{~Pb}$ activity was determined by subtracting the average supported activity (average of ${ }^{214} \mathrm{~Pb}$, ${ }^{214} \mathrm{Bi}$ and ${ }^{226} \mathrm{Ra}$ ) from the total activity for each sample. The calculations were based on the Constant Initial Concentration model (for review, see, e.g., Carroll \& Lerche [2003]) that assumes that the ${ }^{210} \mathrm{~Pb}$ excess concentration in surface sediments is constant over time and the ${ }^{210} \mathrm{~Pb}$ excess flux to the surface of the sediments together with the SR are proportionally variable. The assumption of a closed system in this model imposes that the ${ }^{210} \mathrm{~Pb}$ excess activity profile shall decrease exponentially with depth. The SR was determined using the following equation:

$$
\mathrm{SR}=\lambda \times z \times\left(\ln \left(A_{0} / A_{z}\right)\right)^{-1},
$$

where $\lambda$ is the ${ }^{210} \mathrm{~Pb}$ disintegration constant $(=0.03118$ $\left.\mathrm{yr}^{-1}\right), z$ is a depth in a core $(\mathrm{cm}), A_{0}$ is the ${ }^{210} \mathrm{~Pb}$ excess concentration at the surface (below the mixing layer) and $A_{z}$ is the ${ }^{210} \mathrm{~Pb}$ excess concentration at depth $z$ (bottom layer of the interval). The ${ }^{210} \mathrm{~Pb}$-derived SR was corroborated by the first occurrence of ${ }^{137} \mathrm{Cs}$ as a marker of the early 1950s (Robbins \& Edgington 1975).

AMS ${ }^{14} \mathrm{C}$ ages were performed at the Poznań Radiocarbon Laboratory, Poland, on nine monospecific samples of $N$. pachyderma, except for two samples at 4.5-6.5 $\mathrm{cm}$ and 13-14 cm, where all available planktic foraminifera were picked (Table 1). All samples were picked from the 100-500- $\mu \mathrm{m}$ size fraction. The dates were calibrated into calendar ages using the calibration program CALIB Rev. 7.0.2 (Stuiver \& Reimer 1993) and the Marine 13 calibration curve (Reimer et al. 2013). A global average marine reservoir age of 400 radiocarbon years and $7 \pm 11{ }^{14} \mathrm{C}$ years of local deviation $(\Delta R)$ was applied (Mangerud et al. 2006). This deviation may vary in time but is unknown for our study area. The sample from $2.0-3.5-\mathrm{cm}$ core depth gave a post-1950 age and most likely contained modern, post-A-bomb carbon. Age reversals occurred in samples at $4.5-6.5 \mathrm{~cm}$ and at 9.5-11.5 cm (Table 1). This could be a sign of mixing of sediment due to re-deposition events or, more likely, an 
Table 1 AMS ${ }^{14} \mathrm{C}$ and calibrated dates in core $\mathrm{HH} 12-1206 \mathrm{BC}$.

\begin{tabular}{|c|c|c|c|c|c|c|c|}
\hline Lab no. & $\begin{array}{l}\text { Depth } \\
\text { (cm) }\end{array}$ & $\begin{array}{c}\text { Weight } \\
\text { (mgC) }\end{array}$ & $\begin{array}{c}\text { Age } \\
{ }^{14} \mathrm{C} \mathrm{BP}\end{array}$ & $\begin{array}{c}\text { Calibrated } \\
\text { year } \mathrm{BP}^{\mathrm{b}}\end{array}$ & $\delta^{13} \mathrm{C}$ & Age $A D^{c}$ & $\begin{array}{c}\text { Midpoint AD } \\
\pm 2 \sigma \text { errors }\end{array}$ \\
\hline Poz-59603 & $2-3.5$ & 0.12 & $520 \pm 80^{d}$ & $1-279$ & -3.9 & $1671-1949$ & $1810 \pm 139$ \\
\hline Poz-102419 & $4.5-6.5$ & 0.1 & $460 \pm 40^{d}$ & $160-198$ & -22.6 & $1752-1790$ & $1771 \pm 19$ \\
\hline Poz-57342 & $9.5-11.5$ & 0.8 & $900 \pm 80^{d}$ & $357-644$ & -16.2 & 1306-1593 & $1450 \pm 144$ \\
\hline Poz-102418 & $13-14$ & 0.31 & $580 \pm 35$ & $94-292$ & -4.1 & 1658-1856 & $1757 \pm 99$ \\
\hline Poz-66095 & $14-16$ & 0.14 & $830 \pm 110$ & $258-634$ & -14.6 & 1316-1692 & $1504 \pm 188$ \\
\hline Poz-59605 & $19-20$ & 0.48 & $1175 \pm 30$ & $652-779$ & 0.3 & 1171-1298 & $1234 \pm 63$ \\
\hline Poz-102417 & $22-22.5$ & 0.35 & $1515 \pm 30$ & $966-1158$ & -2.6 & 792-984 & $888 \pm 96$ \\
\hline Poz-66211 & $23.5-25$ & 0.19 & $1870 \pm 70$ & 1272-1560 & -17.6 & $390-678$ & $534 \pm 144$ \\
\hline Poz-57343 & $30-31$ & 0.12 & $2320 \pm 80$ & 1724-2132 & -4.3 & $183 \mathrm{BC}-226$ & $21 \pm 205$ \\
\hline
\end{tabular}

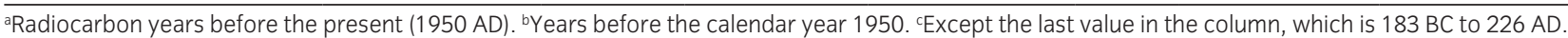
${ }^{\mathrm{d}}$ Date not used in age model.

error associated with the very small amount of material (0.08-0.1 mgC) analysed (Table 1). The aforementioned three dates were not used in the construction of the age model (see later). The calibrated ages are reported as years $\mathrm{AD}$ with a $2 \sigma$ standard error.

Elemental ratios of $\mathrm{Mg} / \mathrm{Ca}$ (for palaeo-temperature) and $\mathrm{Al} / \mathrm{Ca}$ (for control of potential clay contamination) were measured on 60-130 specimens per sample of N. pachyderma $(0.5-2 \mathrm{~cm}$ resolution). Well-preserved, pristine shells were picked from the 150-180- $\mathrm{mm}$ size-fraction, crushed and cleaned in the clean laboratory at the Alfred Wegener Institute in Bremerhaven, principally following the protocol of Barker et al. (2003). The procedure included four steps: (1) clay removal with boron-free Milli-Q water and methanol, (2) oxidation of organic matter in $\mathrm{NaOH}$-buffered $\mathrm{H}_{2} \mathrm{O}_{2}$, (3) weak acid leach in $0.001 \mathrm{~N} \mathrm{HNO}_{3}$ and (4) carbonate dissolution in $60 \mu \mathrm{l}$ of $1 \mathrm{~N} \mathrm{HNO}_{3}$. Subsequently, an aliquot of $5 \mu \mathrm{l}$ from each sample was diluted with $200 \mu \mathrm{l}$ of $2 \% \mathrm{HNO}_{3}$ to determine the Ca concentration. The remaining residue was diluted with $2 \% \mathrm{HNO}_{3}$ to obtain a Ca concentration of 15-20 ppm. The samples were analysed using a $\mathrm{Nu}$ AttoM high-resolution double-focusing inductively coupled plasma mass spectrometer at the Alfred Wegener Institute. Since the sample material was very limited and to avoid matrix effects in the plasma, analyses were conducted at a Ca concentration of about $15 \mathrm{ppm}$. Five replications were carried out for each sample, where the average repeatability for $\mathrm{Mg} / \mathrm{Ca}$ among the five replicates was $0.95 \pm 0.47 \%$ (relative standard deviation). For this study, the measurement uncertainty was determined by analysing the carbonate standard JCt-1 (giant clam), yielding $\mathrm{Mg} / \mathrm{Ca}$ ratios of $1.28 \pm 0.05(2 \sigma) \mathrm{mmol}$ $\mathrm{mol}^{-1}$, which is within $1 \%$ of the values reported in the literature (Inoue et al. 2004; Hathorne et al. 2013). In addition, long-term reproducibility of $\mathrm{Mg} / \mathrm{Ca}$ analyses is monitored by regular analysis of the carbonate standard
JCp-1, yielding $3.94 \pm 0.15(2 \sigma) \mathrm{mmol} \mathrm{mol}^{-1}$ over a period of about two years.

The measured $\mathrm{Mg} / \mathrm{Ca}$ ratios were used to calculate temperatures $\left(\mathrm{SST}_{\mathrm{Mg} / \mathrm{Ca}}\right)$ by using the species-specific $(N$. pachyderma) linear equation of Kozdon et al. (2009):

$$
\mathrm{Mg} / \mathrm{Ca}\left(\mathrm{mmol} \mathrm{mol}{ }^{-1}\right)=0.13 * T+0.35,
$$

where this calibration is based on core-top samples of $N$. pachyderma from the Nordic seas and produces reliable $\mathrm{SST}_{\mathrm{Mg} / \mathrm{Ca}}$ estimates at temperatures above about $3{ }^{\circ} \mathrm{C}$ (Kozdon et al. 2009).

Stable isotopes were measured on three planktic foraminiferal species: N. pachyderma, T. quinqueloba and Globigerinita uvula. These species were chosen as representatives for the surface conditions (G. uvula, average living depth of 15 m [Parker 1962; Rebotim et al. 2017]), near-surface conditions (T. quinqueloba, not deeper than $50 \pm 25 \mathrm{~m}$ [Simstich et al. 2003]) and subsurface conditions (N. pachyderma, 100-250-m water depth [Bauch et al. 1997; Simstich et al. 2003; Pados \& Spielhagen 2014]); see “Discussion" section. Measurements were performed at the Leibniz Laboratory for Radiometric Dating and Stable Isotope Research in Kiel, on size-fractions 125-150 $\mathrm{m}$ (N. pachyderma), 150-180 $\mathrm{m}$ (T. quinqueloba) and 100-150 $\mathrm{mm}($ G. uvula). Results refer to the V-PDB standard. The external analytical reproducibility was $<0.06 \%$ and $<0.03 \%$ or for $\delta^{18} \mathrm{O}$ and $\delta^{13} \mathrm{C}$, respectively. Measurements on all three species were carried out at $0.5-$ 2-cm intervals. Between 7- and 10-cm core depth, T. quinqueloba and G. uvula were absent and could not be analysed.

Palaeo subsurface $\delta^{18} \mathrm{O}_{\text {water }}$ vs. V-SMOW was calculated based on the $\mathrm{Mg} / \mathrm{Ca}$ - reconstructed SSTs (see earlier) in conjunction with the following equation (Shackleton 1974):

$$
\begin{aligned}
T\left({ }^{\circ} \mathrm{C}\right)= & 16.9-4^{*}\left(\delta^{18} \mathrm{O}_{\text {foram }} \text { Vs. V-PDB }+\delta^{18} \mathrm{O}_{\text {vital effect }}\right. \text { Vs. } \\
& \text { V-PDB } \left.-\delta^{18} \mathrm{O}_{\text {water }} \text { Vs. V-SMOW }\right)
\end{aligned}
$$


where $\delta^{18} \mathrm{O}_{\text {water }}$ is the standard V-SMOW. Conversion from the SMOW scale to calcite on the V-PDB scale was done by subtracting $0.2 \%$ (Shackleton 1974).

\section{Results}

\section{Temperature, salinity and carbonate chemistry of the study area}

The CTD data from April show the coldest surface temperatures of $4.1-4.7^{\circ} \mathrm{C}$ and the lowest salinity (Fig. 2a, b). The CTD data from July show the presence of a mixed layer ca. $50 \mathrm{~m}$ in thickness with meltwater characterized by low salinity and relatively high temperatures of 5.4-7.9 ${ }^{\circ} \mathrm{C}$. The surface meltwater layer in October shows the highest temperature of $6.3{ }^{\circ} \mathrm{C}$ (Fig. 2a, b). Below the meltwater and surface mixed layer from about 50-m to 500-600-m water depth, a thick layer of warm and saline Atlantic Water is defined by temperatures ranging from 2.2-4.7 ${ }^{\circ} \mathrm{C}$ in April to $5.4{ }^{\circ} \mathrm{C}$ in July and from $1.5^{\circ} \mathrm{C}$ to $6.3^{\circ} \mathrm{C}$ in October (Fig. 2a, b). Below the Atlantic Water layer, cold intermediate waters $\left(T<0{ }^{\circ} \mathrm{C}\right)$ generated by convection in the Nordic seas are found (e.g., Blindheim et al. 2000).

The upper $200 \mathrm{~m}$ are well saturated with $\Omega_{\mathrm{Ca}^{\prime}}$ ranging from 2.80 at the surface to 2.66 near 200-m water depth (Fig. 2a, c). The carbonate ion concentration $\left[\mathrm{CO}_{3}{ }^{2-}\right]$ and $\mathrm{pH}$ show a decrease from the surface to 200-m water depth (Fig. 2a, c). In both July 2014 and October 2012, maximum absolute abundances of planktic foraminifera are found at $0-50-\mathrm{m}$ water depth, the water layer that represents near-surface to surface water (Supplementary Fig. Sla, b). In July 2014, the lowest abundance is observed at 50-100-m water depth, while relatively high abundances are recorded at 100-200-m water depth, which is occupied by Atlantic Water (Supplementary Fig. Sla).

\section{Sediment core HH12-1206BC}

\section{Construction of the age model and SRs}

The age model and the SRs are constructed based on the ${ }^{210} \mathrm{~Pb}$ and ${ }^{137} \mathrm{Cs}$ activity profiles and the AMS ${ }^{14} \mathrm{C}$ ages. Because of the reversed ${ }^{14} \mathrm{C}$ dates within the interval $6.5-\mathrm{ca} .11 .5 \mathrm{~cm}$, only six AMS ${ }^{14} \mathrm{C}$ ages are used in the age model (Table 1, Fig. 3b). The age model indicates that the core spans the time period from ca. 21 to ca. $2012 \mathrm{AD}$ (Fig. 3b). A constant SR between the dated levels is assumed. The mean SR is about $16 \mathrm{~cm}$ $\mathrm{Ky}^{-1}$ (Fig. 3b). Minimum rates of about $6 \mathrm{~cm}$ occur between ca. 1420 and ca. 1060 AD, while maximum rates of about $53 \mathrm{~cm} \mathrm{Ky}^{-1}$ occur in the upper part (ca. 1960 AD-present). The period from ca. 1800 to ca. $1950 \mathrm{AD}$ is considered to contain potential re-deposition events and is therefore interpreted with great caution.

Because chronology with the ${ }^{14} \mathrm{C}$ method over the last 70 years or so is problematic on the account of variations in the ${ }^{14} \mathrm{C}$ input caused by nuclear bomb testing, the short-lived ${ }^{210} \mathrm{~Pb}$ and ${ }^{137} \mathrm{Cs}$ radionuclide-based SRs for the core top sediments have been estimated. Even though a reliable chronology over the last seven decades cannot be obtained using ${ }^{14} \mathrm{C}$, an agreement between the long-term SRs and short-term SRs is useful in the interpretation of the ${ }^{210} \mathrm{~Pb}$ profiles (half-life: 22.3 years) by extrapolation to longer timescales. In core HH12$1206 \mathrm{BC}$, the ${ }^{210} \mathrm{~Pb}$ and ${ }^{137} \mathrm{Cs}$ activity profiles show a typical decrease with the depth to $6.25 \mathrm{~cm}$. The 3 -cm-thick surface layer has the highest and near-uniform activities, indicating sediment mixing and the presence of an upper surface mixed layer, which suggests that the box core recovered an undisturbed sediment surface. From $3.25 \mathrm{~cm},{ }^{210} \mathrm{~Pb}$ activities decrease exponentially down to $6.25 \mathrm{~cm}$ of the core. The average apparent SR is $80 \mathrm{~cm} \mathrm{Ky}^{-1}$ with a maximum of $100 \mathrm{~cm} \mathrm{Ky}^{-1}$ (Fig. 3a). The three major peaks in ${ }^{137} \mathrm{Cs}$ activity related to the atmospheric nuclear bomb testing in the 1950s to mid70s, and the Chernobyl reactor explosion in 1986 (Kunzendorf \& Larsen 2002), have been recorded in marine sediments of the North Atlantic and the Barents Sea (e.g., Grøttheim 1999). These peaks are absent in core $\mathrm{HH} 12-1206 \mathrm{BC}$, further supporting the interpretation that the upper $3 \mathrm{~cm}$ is a mixed layer. Including the approximately $3 \mathrm{~cm}$ thick mixed surface layer, the average SR based on ${ }^{137} \mathrm{Cs}$ activity becomes $70 \mathrm{~cm} \mathrm{Ky}^{-1}$ (Fig. 3a), which is placed between the ${ }^{14} \mathrm{C}$-derived value of ca. $53 \mathrm{~cm} \mathrm{Ky}^{-1}$ and the ${ }^{210} \mathrm{~Pb}$-derived value of $80 \mathrm{~cm} \mathrm{Ky}^{-1}$.

\section{Sediment composition}

The sediment is dominated by clay and silt (61-96\%), with generally low sand content. A small increase in sand content occurs towards the top of the core (Supplementary Fig. S2a). The concentration of IRD > $1000 \mu \mathrm{m}$ and 500-1000 $\mu \mathrm{m}$ is generally low. The IRD 500-1000 $\mu \mathrm{m}$ increases towards the top of the core (Supplementary Fig. S2b). The \% TOC and \% TC are low and nearly constant throughout the entire record (Supplementary Fig. S2c). The $\% \mathrm{CaCO}_{3}$ shows a slight decrease towards the core top reaching a low value of about $10 \%$ at $3-\mathrm{cm}$ sediment depth and returning to values of $20-22 \%$ afterwards (Supplementary Fig. S2c). 


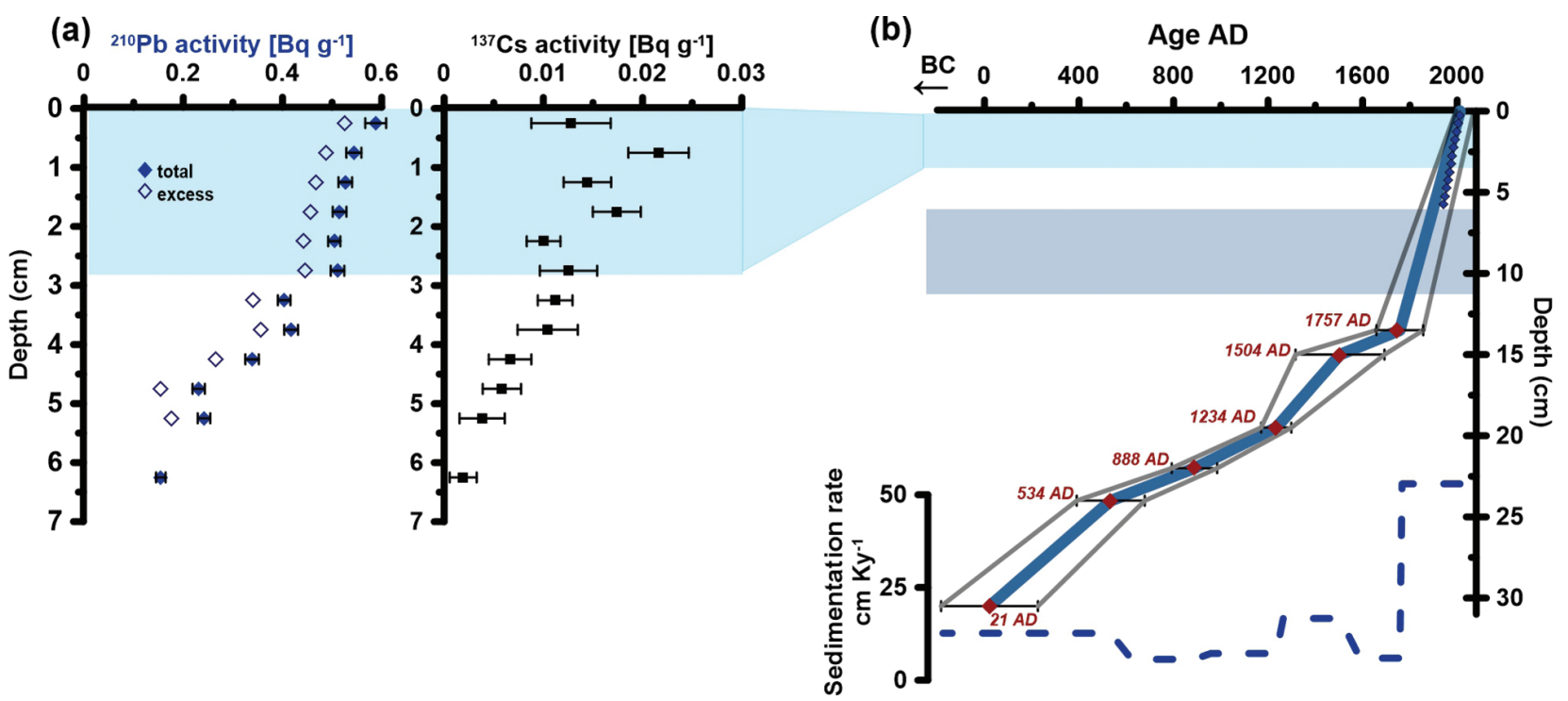

Fig. 3 Age model based on ${ }^{210} \mathrm{~Pb},{ }^{137} \mathrm{CS}$ and AMS ${ }^{14} \mathrm{C}$ datings in core $\mathrm{HH} 12-1206 \mathrm{BC}$. (a) Total and excess ${ }^{210} \mathrm{~Pb}$ activity profiles and ${ }^{137} \mathrm{Cs}$ activity profile. (b) Age-depth plot of calibrated AMS ${ }^{14} \mathrm{C}$ datings. In (a), horizontal bars mark $2 \sigma$ uncertainties. In (b), dates and diamonds in red indicate calibrated radiocarbon ages, and error bars of AMS dates indicated by grey-lined field represent $2 \sigma$ standard deviation. Dark blue diamonds indicate the age model based on ${ }^{210} \mathrm{~Pb}$ activity. The errors in this age model increase with depth (from 0.3 years at $0.25 \mathrm{~cm}$ to 7 years at $5.75 \mathrm{~cm}$, not shown). The light blue areas in (a) and (b) represent a mixing of sediment in the upper $3 \mathrm{~cm}$ indicated by ${ }^{210} \mathrm{~Pb}$ activity profiles. In (b), the grey area shows intervals of reversed ${ }^{14} \mathrm{C}$ dates. $\mathrm{SR}$ is shown at the bottom of (b).

\section{Stable isotopes}

The $\delta^{18} \mathrm{O}$ values of $N$. pachyderma and T. quinqueloba generally show an increasing trend with lower $\delta^{18} \mathrm{O}$ values from about $1800 \mathrm{AD}$ (Fig. $4 \mathrm{a}-\mathrm{c}$ ). The record of T. quinqueloba is more variable than the record of $N$. pachyderma. The $\delta^{18} \mathrm{O}$ values of $G$. uvula show the opposite trend of the other two species, but of lower amplitude. The $\delta^{13} \mathrm{C}$ values of $N$. pachyderma, T. quinqueloba and $G$. uvula show similar trends until about $1800 \mathrm{AD}$ (Fig. $4 \mathrm{~d}-\mathrm{f}$ ). The $\delta^{13} \mathrm{C}$ values of $G$. uvula are low between about $400 \mathrm{AD}$ and about $1770 \mathrm{AD}$ but are otherwise high.

\section{Planktic foraminifera and recent planktic foraminifera in the study area}

The plankton tow data were collected in two different years, at different seasons and depth intervals (Supplementary Fig. S1; see Methods section). For better comparison between the relative distributions of species observed in the sediment record versus the water column, we combined all the planktic foraminiferal specimens found in the plankton tow samples to represent the entire upper $200 \mathrm{~m}$ of the water column in the two respective years. The living planktic foraminifera are dominated by T. quinqueloba $(>80 \%)$ in both years of collection, with $>10 \%$ of living N. pachyderma,
$<4 \%$ G. uvula and $<1 \% N$. incompta (Fig. $5 \mathrm{~g}, \mathrm{~h}$ ). In the sediment surface sample (which, according to our age model, represents nine years of annual foraminiferal production), the difference in relative abundances of T. quinqueloba and N. pachyderma is only $10 \%$, while G. uvula represents $20 \%$ of the planktic foraminiferal fauna (Fig. 5f).

The fossil planktic foraminiferal assemblages in core HH12-1206BC are dominated by N. pachyderma (33$88 \%$ ). T. quinqueloba, the second most abundant species, constitutes 9-43\% (Fig. 5a, b). The third most abundant species is G. uvula (2-20\%), which has recently been found in increasing proportions at the western Barents Sea margin constituting up to $64 \%$ of the planktic foraminiferal assemblages (Hulot 2015; Fig. 5c). Other species present are Neogloboquadrina incompta (Fig. 5d), Globigerinita glutinata and Globigerina bulloides (the last two are not shown as they are always $<1 \%$ ). The most marked changes in species distribution patterns occur in the last 200 years or so (Fig. 5a-e). The mean shell-weights of both size fractions $100-125 \mu \mathrm{m}$ and $150-180 \mu \mathrm{m}$ of $N$. pachyderma and T. quinqueloba show similar and relatively low variability. The highest shell weights are recorded at about 180-340 AD, 1100-1350 AD and 1500-1770 AD (Supplementary Fig. S2d, Fig. 6f). The percentage of shell fragmentation in the entire record is rather low except for short-lasting intervals of high fragmentation 


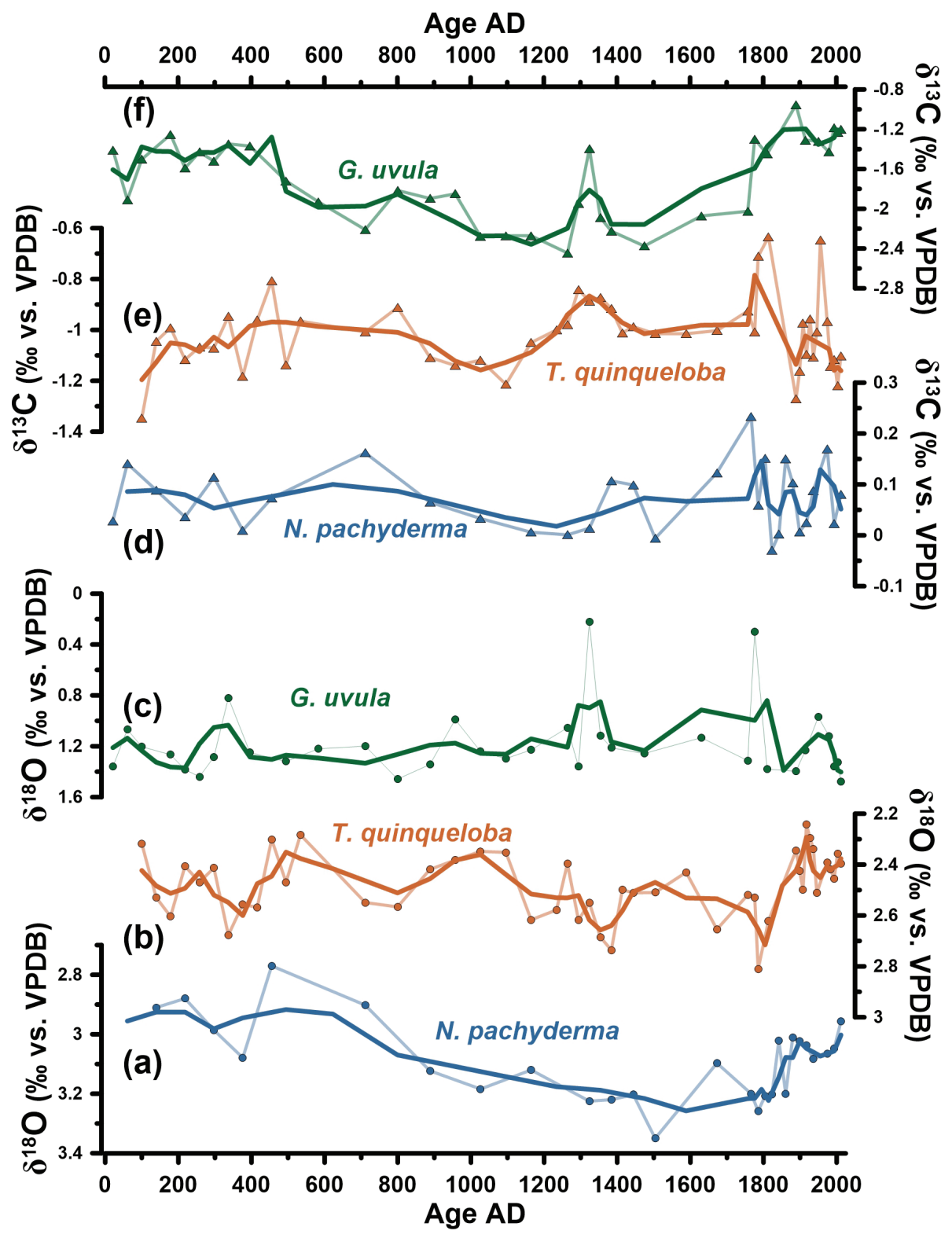

Fig. 4 Stable isotope (thin lines represent raw data and thick lines represent 3-point moving average) records in core $\mathrm{HH} 12-1206 \mathrm{BC}$. (a) $\delta^{18} \mathrm{O}$, (d) $\delta^{13} \mathrm{C}$ of Neogloboquadrina pachyderma, (b, e) Turborotalita quinqueloba and (c, f) Globigerinita uvula.

at approximately $140 \mathrm{AD}, 1600 \mathrm{AD}$ and $1770 \mathrm{AD}$ to the present (Fig. 6e).

\section{SST records}

SSTs based on $\mathrm{Mg} / \mathrm{Ca}$ ratios $\left(\mathrm{SST}_{\mathrm{Mg} / \mathrm{Ca}}\right)$ vary between 3.1 and $6.2{ }^{\circ} \mathrm{C}$ (Fig. 6a). These temperatures are very similar to the temperatures $\left(3.9-5.4{ }^{\circ} \mathrm{C}\right)$ recorded at $100-250-\mathrm{m}$ water depth by the three CTD casts (Fig. 2a, b). The SSTs obtained by transfer functions ( $\mathrm{SST}_{\mathrm{TF}}$ ) range between 2.0 and $7.0{ }^{\circ} \mathrm{C}$ (Fig. 6h). The highest temperatures in this record are found over the last 50 years and fairly closely follow the instrumental record of global temperature anomalies (Fig. 6h).

\section{Discussion}

\section{Interpretation of environmental conditions at Storfjorden Fan 21-2014 AD}

Based on the modern main depth habitats of the three dominating species, we interpret the living depths for T. quinqueloba (e.g., Hemleben et al. 1989; Carstens et al. 1997; Simstich et al. 2003; Sarnthein \& Werner 2017) 


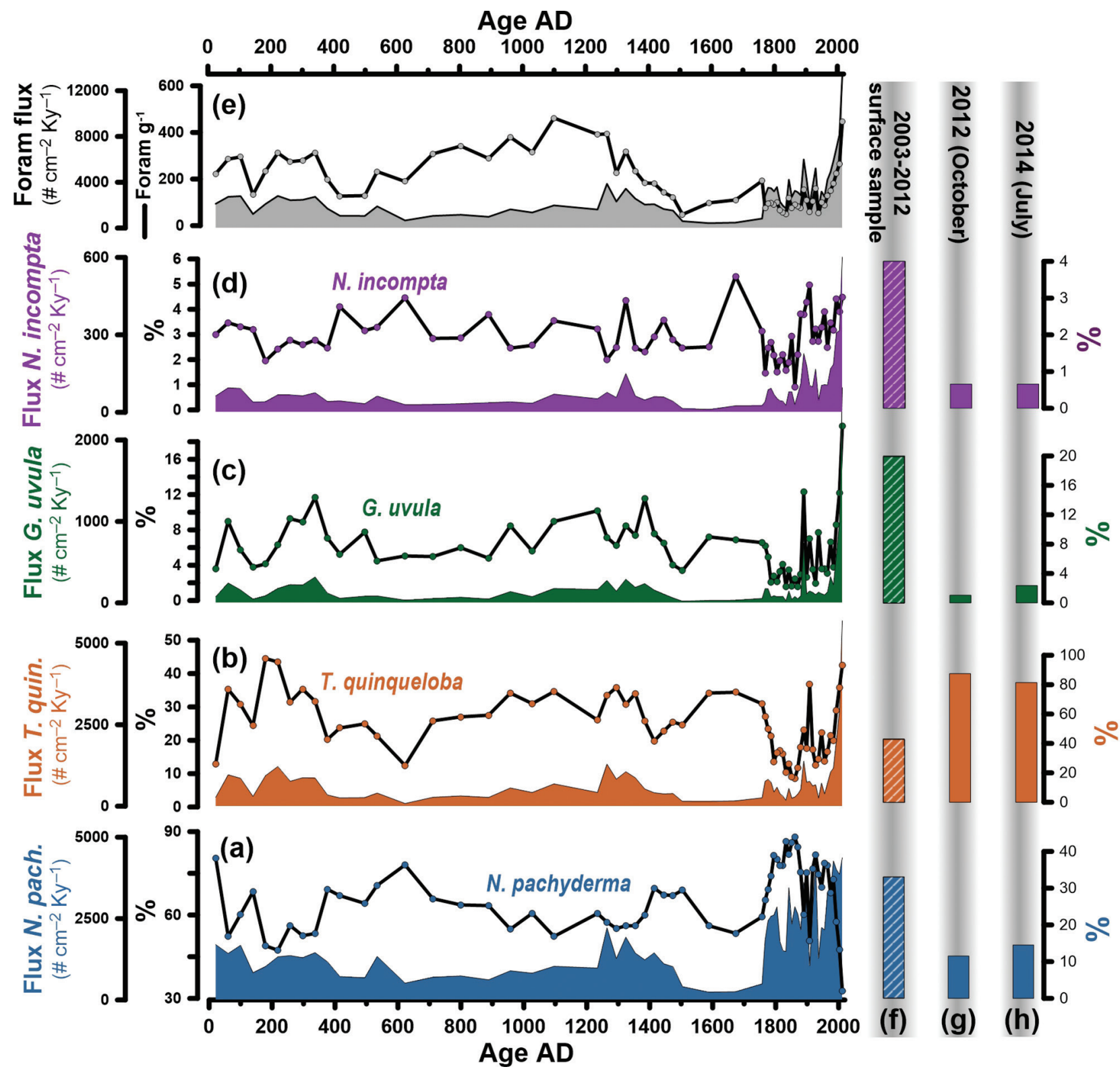

Fig. 5 Planktic foraminiferal distribution data of core HH12-1206BC (a-e): relative abundance (line) and flux (shaded area; number of specimens cm² $\mathrm{Ky}^{-1}$ ) of (a) Neogloboquadrina pachyderma, (b) Turborotalita quinqueloba, (c) Globigerinita uvula, (d) Neogloboquadrina incompta and (e) total flux and concentration (number of specimens per gram dry weight sediment) of planktic foraminifera. Modern data (f-h): (f) relative abundances of planktic foraminiferal species in surface sediment sample ( $5 \mathrm{~mm}$ corresponds to nine years of deposition according to age model), ( $\mathrm{g}$, $\mathrm{h}$ ) relative abundances of living specimens of $N$. pachyderma (blue), T. quinqueloba (orange), G. uvula (green) and N. incompta (purple) collected in (g) 2012 and (h) 2014 at the coring site. Note differences in scale for live and fossil percentages.

and G. uvula (e.g., Boltovskoy et al. 1996; Hulot 2015; Rebotim et al. 2017; Schiebel et al. 2017; H. Bauch, unpubl. data) as indicators of near-surface to surface water conditions and productivity, respectively (75ca. $0 \mathrm{~m}$ ). Neogloboquadrina pachyderma and N. incompta, which in Fram Strait prefer mainly Atlantic Water, are interpreted as indicators of subsurface water conditions and productivity at depths of about 250-75 m (e.g., Bé \& Tolderlund 1971; Johannessen et al. 1994; Volkmann \& Mensch 2001; Simstich et al. 2003; Pados \& Spielhagen 2014; Pados et al. 2015; Sarnthein \& Werner 2017). Furthermore, we associate the $\mathrm{SST}_{\mathrm{TF}}$ estimated for $10-\mathrm{m}$ water depth and the $\mathrm{SST}_{\mathrm{Mg} / \mathrm{Ca}}$ based on N. pachyderma with surface and subsurface water temperatures, respectively. 


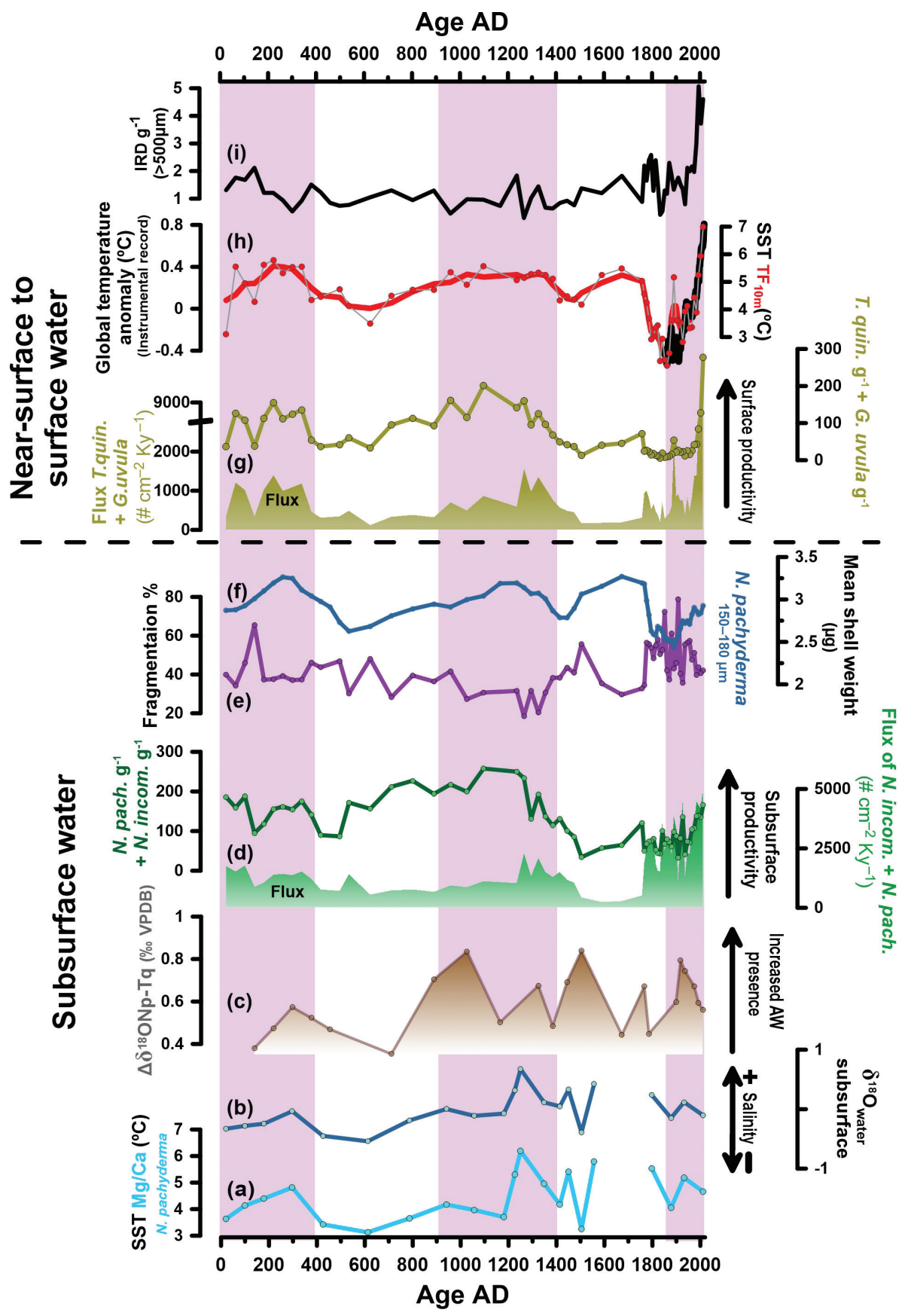

Fig. 6 Reconstructed late Holocene oceanography at Storfjorden Fan in core HH12-1206BC. (a) Mg/Ca-ratio-based SST on Neogloboquadrina pachyderma representing subsurface temperatures (see text for explanation), (b) subsurface $\delta^{18} \mathrm{O}_{\text {water }}$ (c) $\Delta \delta^{18} \mathrm{O}_{\mathrm{ND} \text {-Tq }}$ as an indicator of increased/decreased presence of warm Atlantic Water versus Polar Water, (d) sum of flux (number of specimens $\mathrm{cm}^{-2} \mathrm{Ky}^{-1}$ ) and concentrations (number of specimens per gram) of $\mathrm{N}$. pachyderma and $\mathrm{N}$. incompta as an indicator for subsurface productivity, (e) \%fragmentation, (f) 3-point running average of mean shell weight of $\mathrm{N}$. pachyderma (150-180 $\mu \mathrm{m})$, (g) sum of flux and concentrations of T. quinqueloba and G. uvula as an indicator for near-surface to surface productivity, (h, right) transfer-function based SST TF 10-m water depth representing SSTs (red line) and (left) instrumental record of global temperature anomaly (black line; Berkeley Earth 2019) and (i) IRD >500 $\mu \mathrm{m}$ (number of mineral grains per gram). Vertical pink bars mark warmer time intervals. AW: Atlantic Water. 
In addition, small/large differences in $\Delta \delta^{18} \mathrm{O}_{\mathrm{Np}-\mathrm{Tq}}$ are interpreted as an indication of relative increased/decreased presence of warm and salty Atlantic Water in the subsurface to near-surface water (Moffa-Sanchez \& Hall 2017).

\section{Local climate and sea-surface conditions}

High relative abundance and concentration of the subpolar species T. quinqueloba from at about $21 \mathrm{AD}$ indicate the influence of the warm and saline Atlantic Water (Volkmann 2000). The SST estimates representing the subsurface $\left(\mathrm{SST}_{\mathrm{Mg} / \mathrm{Ca}}\right)$ and the surface $\left(\mathrm{SST}_{\mathrm{TF}}\right)$ unanimously confirm the presence of warm and saline water (Fig. 6a, h). At roughly 200-400 AD, high SST and increased salinity $\left(\delta^{18} \mathrm{O}_{\text {water }}\right)$ indicate that the influence of Atlantic Water was at its strongest (Fig. 6a, b, h). Also, the elevated $\Delta \delta^{18} \mathrm{O}_{\mathrm{Np} \text {-Tq }}$ indicates increased presence of Atlantic Water at the subsurface to near-surface (Fig. $6 \mathrm{c})$. The timing indicates an overlap with the later phase of the so-called Roman Warm Period (ca. 200 BC-400 $\mathrm{AD}$ ), described from north-western Europe (e.g., Lamb 1977; Grove 2004); these warmer conditions at the Svalbard margin may have been a local expression of this climatic event (Fig. 6). After about $400 \mathrm{AD}$, the flux of the planktic foraminifera and the percentages and concentrations of T. quinqueloba and G. uvula decreased and became low (Fig. 5b, c, e). Together with the dominance of the polar species $N$. pachyderma, this indicates a change towards cold oceanic conditions, at least at the near-surface to surface layer. The $\mathrm{SST}_{\mathrm{Mg} / \mathrm{ca}}$ and the $\mathrm{SST}_{\mathrm{TF}}$ show a ca. $1{ }^{\circ} \mathrm{C}$ drop in temperature of the subsurface and surface water, compared to before $400 \mathrm{AD}$ (Fig. 6a, h). The low $\Delta \delta^{18} \mathrm{O}_{\mathrm{Np} \text {-Tq }}$ suggests reduced influence of Atlantic Water in the subsurface to near-surface layers (Fig. 6c).

A change to warm surface conditions is indicated by a decrease in the relative abundance of the polar species $N$. pachyderma and a high percentage of subpolar species from ca. 900 AD (Fig. 5a-d). Between ca. 900 and 1400 $\mathrm{AD}$, the average $\mathrm{SST}_{\mathrm{TF}}$ was about $5.9^{\circ} \mathrm{C}$ (Fig. 6h). From about $930 \mathrm{AD}$, the subsurface water warmed, culminating at about $1250 \mathrm{AD}$, when the highest subsurface temperatures and salinity over the entire 2000 years, as indicated by the $\mathrm{SST}_{\mathrm{Mg} / \mathrm{Ca}}$ and $\delta^{18} \mathrm{O}_{\text {water' }}$ occurred (Fig. 6a, b). Also, the high $\Delta \delta^{18} \mathrm{O}_{\mathrm{Np} \text {-Tq }}$ points to increased presence of Atlantic Water at this time (Fig. 6c). All the proxies clearly suggest a dominance of Atlantic Water and warm sea-surface conditions lasting until about 1400 $\mathrm{AD}$. The warming and ameliorated conditions potentially represent a local expression of the well-known Medieval Climate Anomaly recorded in north-western Europe (ca. 900-1400 AD; e.g., Lamb 1977; Grove 2004; Fig. 6).
Between about 1400 and 1500 AD, fairly high-magnitude changes in most proxies suggest unstable subsurface to surface water conditions (Figs. 5, 6). Shifts in all reconstructed SSTs, $\delta^{18} \mathrm{O}$ and $\delta^{13} \mathrm{C}$ values and a relatively high, but gradually decreasing flux of planktic foraminifera in addition to the dominance of the polar species $N$. pachyderma point to a progressive trend towards cold conditions with meltwater at the surface and the presence of the Marginal Ice Zone (Figs. 4, 5a-e, 6a, h). This was probably caused by an increase in sea-ice cover during winters, initiated by the transition to the cooler sea-surface conditions. The following time interval at ca. 1500-1770 AD is characterized by slightly ameliorated conditions indicated by low percentages of $N$. pachyderma and relatively high percentages of $T$. quinqueloba and $G$. uvula, with relatively high $\mathrm{SST}_{\mathrm{TF}}$ showing intermediate warm surface waters (Figs. 5a-c, 6h).

At about $1770 \mathrm{AD}$, the $\mathrm{SST}_{\mathrm{TF}}$ indicates a rapid drop and the following interval, at about 1770-1850 AD, is characterized by the lowest $\mathrm{SST}_{\mathrm{TF}}$ of the past two millennia (Fig. 6h). Between ca. 1770 and ca. $1850 \mathrm{AD}$, a shift to very low foraminiferal concentration dominated by $N$. pachyderma (up to $88 \%$ ) and with very low mean shell weights, high \%fragmentation and markedly increased IRD concentrations indicate a change to harsh ocean conditions in winters and expansion of the Marginal Ice Zone, with enhanced sea ice and iceberg rafting during summers (Figs. 5a-e, 6e, f, i). Together with the minimum of surface ocean temperatures indicated by our reconstructed SST $\left(\mathrm{SST}_{\mathrm{TF}}\right.$ ca. $2{ }^{\circ} \mathrm{C}$ at ca. $1850 \mathrm{AD}$ and $\mathrm{SST}_{\mathrm{Mg} / \mathrm{Ca}}$ ca. 3.3 ${ }^{\circ} \mathrm{C}$ at about $1500 \mathrm{AD}$; Fig. 6a, h), the period of roughly 1400-1850 AD has been a local expression of the wellknown cold event in northern Europe: the Little Ice Age, which occurred at about 1400-1850 AD (e.g., Lamb 1977; Grove 2004).

During the last ca. 200 years, the relative abundance of the cold species $N$. pachyderma decreased to the minimum of the entire record (Fig. 5a). This trend seems to have continued until 2014, as indicated by the relative abundances of the three species recorded by plankton tows (Fig. 5g, h). Together with high $\Delta \delta^{18} \mathrm{O}_{\mathrm{Np}-\mathrm{Tq}}$, which indicates an increased presence of Atlantic Water, and high $\mathrm{SST}_{\mathrm{TP}}$ this clearly points to the sea-surface conditions during the last century experiencing a warming (Fig. 6c, h). The increased IRD indicates more sea ice/icebergs after 1850 $\mathrm{AD}$ (Fig. 6i). The increasing $\mathrm{SST}_{\mathrm{TF}}$ at Storfjorden Fan correlates with increasing global temperatures measured by instrumental records and representing a global warming signal (Fig. 6h; Berkeley Earth 2019). While the surface temperature of the past 60 years has reached a maximum of ca. $7{ }^{\circ} \mathrm{C}$ (average $5.4{ }^{\circ} \mathrm{C}$ ), as indicated by $\mathrm{SST}_{\mathrm{TP}}$ the temperatures of the subsurface water have increased only slightly, as indicated by SST $_{\mathrm{Mg} / \mathrm{Ca}}$ (Fig. 6a, h). 


\section{Palaeoproductivity}

The high concentration of planktic foraminifera in seasonally sea-ice-covered areas, such as the Storfjorden Fan area, is related to the presence of the Marginal Ice Zone and its high primary production. The conditions of the sea-ice margin promote higher production of the diatoms that are considered the major food source for such species as $N$. pachyderma, T. quinqueloba and $N$. incompta (Hemleben et al. 1989). Neogloboquadrina pachyderma has been classified as a deep-dwelling subsurface species (see earlier) that calcifies around 200-m water depth (Volkmann \& Mensch 2001; Simstich et al. 2003; Sarnthein \& Werner 2017), and N. incompta is a temperate water species that in the Nordic seas prefers warm Atlantic Water (e.g., Bé \& Tolderlund 1971). Therefore, we link increased subsurface productivity to high fluxes and concentrations of $N$. pachyderma and $N$. incompta. Similarly, high fluxes and concentrations of T. quinqueloba and G. uvula are interpreted as increased surface to near-surface productivity.

At Storfjorden Fan, the subsurface and surface to near-surface productivity of planktic foraminifera show a generally concurrent response to the climatic and oceanographic development, with higher productivity influenced by Atlantic Water (Fig. 6). Very high, but variable, planktic foraminiferal fluxes and concentrations indicate highest productivity at ca. 1300-1500 AD, 1750-1860 AD and over the last 50 years (Fig. $6 \mathrm{~d}, \mathrm{~g}$ ). These periods with enhanced planktic foraminiferal fluxes likely represent either an approach or a retreat of the productive Marginal Ice Zone occurring during the transitional phases between warm to cold and cold to warm conditions. Seasonally, stable and stratified surface water conditions created by sea-ice melting within the Marginal Ice Zone favour phytoplankton blooms leading to increased abundances and subsequent high fluxes of planktic foraminifera (Alexander 1980; Smith et al. 1987; Williams 1993).

The minimum productivity of the past 2000 is recorded during the cold period between about 1500 and 1770 AD (Fig. 6d, g). This was probably due to harsh sea-icecovered winters, and summers packed with sea ice and limited food availability. Light limitations hinder diatoms and other algae usually from growing intensely under permanent ice cover (e.g., Michel et al. 1988; Cota \& Sullivan 1990; Gosselin et al. 1990).

These productivity changes are confirmed by $\delta^{13} \mathrm{C}$ values measured on $N$. pachyderma, T. quinqueloba and $G$. uvula (Fig. $4 \mathrm{~d}-\mathrm{f}$ ). Changes in $\delta^{13} \mathrm{C}$ values can be attributed to changes in palaeoproductivity and ventilation of surface and near-surface waters (Duplessy 1978) if other chemical, biological and physical factors can be ruled out (e.g., Spero et al. 1997; Bemis et al. 2000; Peeters et al. 2002). The fairly similar general trends in $\delta^{13} \mathrm{C}$ until ca. $1800 \mathrm{AD}$ in the three species are therefore probably related to similar productivity and ventilation levels in the upper ca. $250 \mathrm{~m}$ of the water column (Fig. 4d-f). High $\delta^{13} \mathrm{C}$ values correlate with the maxima in planktic fluxes and low values with the minima. During the last roughly 200 years, the $\delta^{13} \mathrm{C}$ values in the three species deviated. The $\delta^{13} \mathrm{C}$ values of $N$. pachyderma and $T$. quinqueloba decreased, whereas the $\delta^{13} \mathrm{C}$ values of $G$. uvula increased, suggesting decoupling of the productivity and ventilation in the surface waters from the waters below, which may be an indication of stratification near the surface.

\section{Preservation and carbonate chemistry}

Similar and relatively low variability of mean shell weights of both size fractions 100-125 and 150-180 $\mu \mathrm{m}$ of $N$. pachyderma and T. quinqueloba indicate a parallel response to environmental changes and preservation of the two species (Supplementary Fig. S2d). This is confirmed by rather low \%fragmentation that generally shows an opposite pattern to the mean shell-weight record, that is, high \%fragmentation corresponds to low shell weight of planktic foraminifera (Supplementary Fig. S2d, Fig. 6e, f). Better preservation appears to correlate with the warmer periods and an increased influence of Atlantic Water. During the warm time interval of about 21-400 AD, the mean shell weights of $N$. pachyderma and T. quinqueloba peaked at about 200 AD with a maximum of $3.32 \mu \mathrm{g}$ in N. pachyderma (150-180 $\mathrm{gg}$ ). Similar high mean shell weights at ca. $200 \mathrm{AD}$ likewise indicate good preservation at some $317 \mathrm{~km}$ north of our core site (Zamelczyk et al. 2013). This can be attributed to a strong influence of calcium carbonate-rich Atlantic Water (e.g., Huber et al. 2000). From about $400 \mathrm{AD}$ during the colder period, the mean shell weights of $N$. pachyderma and T. quinqueloba decreased together with the shell fragmentation (Supplementary Fig. S2d, Fig. 6e, f). This indicates a deterioration of the calcification conditions for these species rather than dissolution due to diagenetic changes in the sediment. High shell weights and the clearly low fragmentation occurred during the warm period at 900-1400 AD, again indicating good preservation. During the cold period of ca. 1400-1530 AD, the mean shell weight of $N$. pachyderma first decreased, and at ca. $1520 \mathrm{AD}$, the \%fragmentation was high, indicating rather severe preservation problems also correlating with a peak in ice rafting (Figs. 6e, f). This is supported by the ca. $1.3^{\circ} \mathrm{C}$ temperature drop in surface water, as indicated by the $\mathrm{SST}_{\mathrm{TF}}$ (Fig. 6h). This may possibly be related to changes in $\left[\mathrm{CO}_{3}{ }^{2-}\right]$ and $\Omega_{\mathrm{Ca}}$ due to more seaice and subsequent melting during peak reproduction 
in the summer months (Manno et al. 2012; Fransson et al. 2013). Around 1530 AD, the mean shellweights increased, whereas the \%fragmentation decreased, implying good preservation. This coincides with the slightly ameliorated conditions, with low to moderate presence of Atlantic Water and increased percentages of T. quinqueloba and G. uvula and relatively high $\mathrm{SST}_{\mathrm{TF}}$ during this time (see discussion earlier; Supplementary Fig. S2d, Figs. 5b, c, 6c, h). We speculate that the moderate presence of Atlantic Water with high $\left[\mathrm{CO}_{3}{ }^{2-}\right]$ compared with Polar Water characterized by low $\left[\mathrm{CO}_{3}{ }^{2-}\right.$ ] (Chierici et al. 2011; Manno et al. 2012), in addition to phytoplankton blooms within the Marginal Ice Zone, provided sufficient calcium carbonate and nutrients for planktic foraminifera to maintain similar calcification rates to those recorded during the warm periods at ca. 21-400 and 900-1400 AD (Supplementary Fig. S2d).

During the last approximately 62 years, the increased SST and enhanced inflow of Atlantic Water are expected to correlate with an increase in the shell weights of $N$. pachyderma and T. quinqueloba. However, the mean shell weights show only a slight weight increase and no change in \%fragmentation (Supplementary Fig. S2d, Fig. 6e, f). It has been shown that carbonate saturation plays an important role in the calcification of foraminiferal shells (Russell et al. 2004; Lombard et al. 2010; Manno et al. 2012). Under low $\left[\mathrm{CO}_{3}{ }^{2-}\right]$, shell calcification rates tend to decrease (Manno et al. 2012). This could be linked to recent ocean acidification, where an increase in $\mathrm{CO}_{2}$ in the ocean leads to a decrease of $\left[\mathrm{CO}_{3}{ }^{2-}\right]$ and a lower level of calcium carbonate saturation (e.g., Chierici et al. 2011). The saturation of calcite $\left(\Omega_{\mathrm{Ca}}\right)$ of $2.2 \pm 0.6$ and $\left[\mathrm{CO}_{3}{ }^{2-}\right]$ of $107 \pm 11 \mu \mathrm{mol}$ $\mathrm{kg}^{-1}$ recorded in April 2015 at our study site fall within the low range of values characteristic for Polar Water (Fig. 2a, c; Chierici et al. 2011). Moreover, the cooling of surface water in the West Spitsbergen Current has resulted in large $\mathrm{CO}_{2}$ absorption in the North Atlantic, which holds greatest amount of anthropogenic $\mathrm{CO}_{2}$ (Olsen et al. 2010). However, as these measurements were taken in early spring, the relatively low values represent a season of sea-ice melting, also supported by low salinity and low temperatures (Fig. 2a, b). As there is no clear relationship between shell weight, concentration, growth of planktic foraminifera and environmental conditions (e.g., carbonate saturation, temperature, productivity, optimum growth conditions; e.g., Weinkauf et al. [2016] and Lischka et al. [2018]), it is impossible to determine whether the low mean shell weights result from ocean acidification or other environmental factors.

\section{Late Holocene changes in water-mass properties and productivity: comparison to other studies}

Except for the anthropogenic global warming (e.g., Abram et al. 2016), climate variability and its spatiotemporal development during the past two millennia has recently been shown to be regional signal and not a global phenomenon (Neukom et al. 2019), aside from a general ocean cooling trend over the last 2000 years (e.g., McGregor et al. 2015). Climatic periods and their timing defined historically in north-western Europe by Lamb (1977) correlate with major changes in proxy records in the North Atlantic and Nordic seas region. They indicate temperature and productivity changes on multidecadal to centennial timescales with prominent cold and warm anomalies (e.g., Jiang et al. 2002; Spielhagen et al. 2011 ; Andresen et al. 2013; Matul et al. 2018). Increased inflow of warm subsurface Atlantic Water from the Norwegian Sea into the Arctic Ocean via the eastern Fram Strait is considered to be responsible for the warm intervals associated with the Roman Warm Period, the Medieval Climate Anomaly and the Recent Warming (Spielhagen et al. 2011; Werner et al. 2011; Zamelczyk et al. 2013; Werner et al. 2016). However, depending on the environmental settings, proximity of the sea-ice edge, availability of nutrients, microfossil types and other proxies, the productivity signals may vary considerably (Matul et al. 2018; Moffa-Sánchez et al. 2019). We compare our temperature estimates and flux of the subsurface dwelling $N$. pachyderma and near-surface to surface living T. quinqueloba and G. uvula as indicators of subsurface and near-surface to surface water productivity, respectively, to other records based on planktic foraminifera and other microfossils indicative of biological production in Fram Strait and northern North Atlantic (Figs. 1, 7; Supplementary Table S1).

At Storfjorden Fan, the beginning of the past two millennia was characterized by a strengthened inflow of Atlantic Water and relatively warm and productive subsurface and near-surface to surface water. At the same time, an enhanced influence of warm Atlantic Water and a low relative abundance of $N$. pachyderma were recorded at a site from the subpolar gyre south of Greenland and Iceland (Moffa-Sánchez \& Hall 2017). In contrast, low surface productivity is indicated by a low flux and concentration of planktic foraminifera from core sites just south of our study area off Spitsbergenbanken on the deep slope (core GIK23258) and on the nearby shelf (Kveithola Trough core JM09-KAl 1GC; Sarnthein et al. 2003; Berben et al. 2014; Fig. 7a-h; Supplementary Table S1). In core GIK23258, a sharp peak in relative abundance of T. quinqueloba occurred at ca. $280 \mathrm{AD}$, 


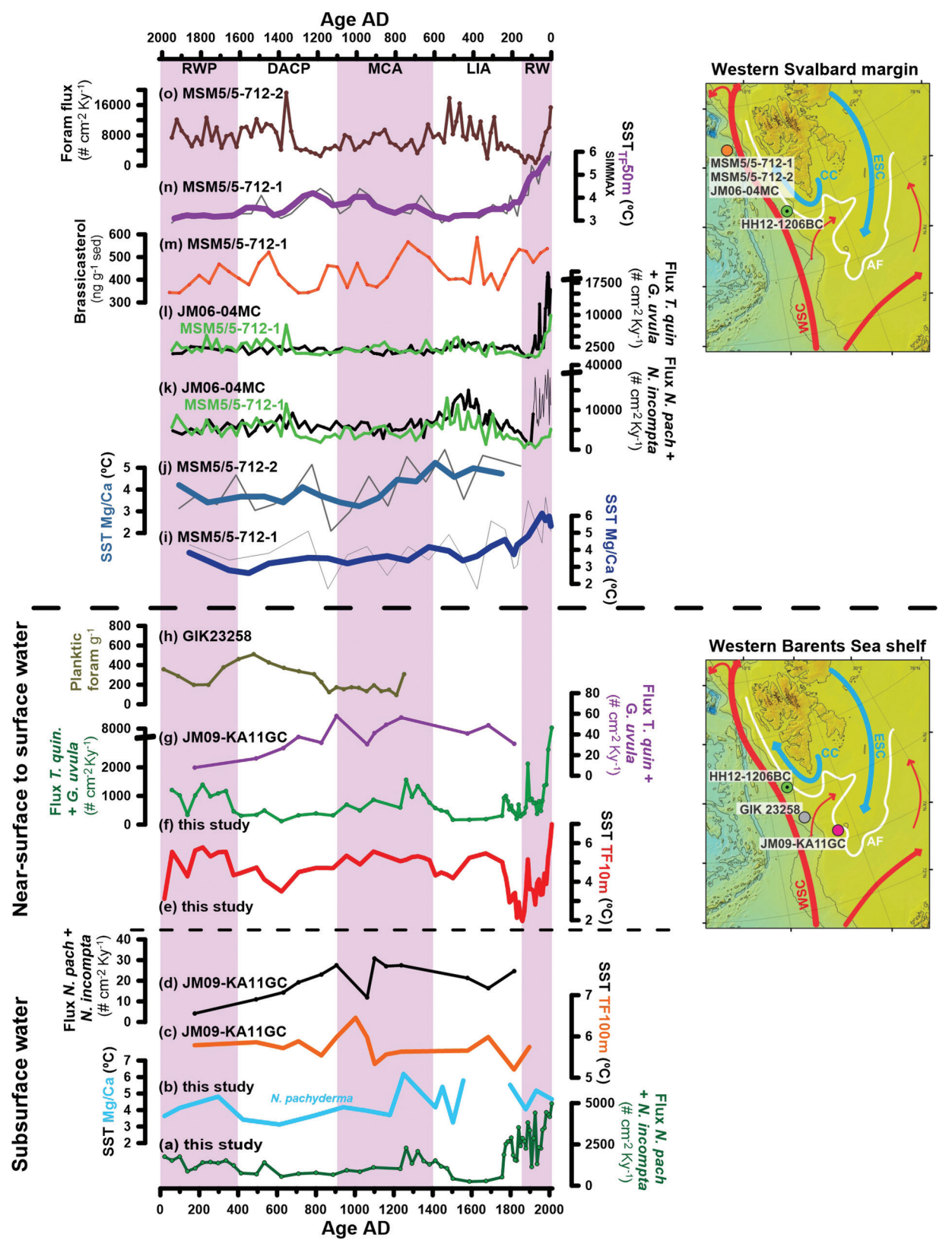

Fig. 7 Comparison of oceanic conditions of the last two millennia at Storfjorden Fan with other records from the eastern Fram Strait. (a, b) Subsurface productivity indicated by the flux of Neog/oboquadrina pachyderma and N. incompta and subsurface Mg/Ca-based palaeotemperature in core HH12-1206BC (this study) compared to (c) subsurface transfer function palaeotemperature based on planktic foraminifera at 100-m water depth and (d) subsurface productivity at Kveithola Trough at the western Barents Sea margin in core JM09-KA11-GC (Berben et al. 2014). Near-surface to surface (e, f) temperature at 10-m water depth and productivity indicated by the flux of Turborotalita quinqueloba and Globigerinita uvula in core HH12-1206BC (this study) compared with (g) the flux of T. quinqueloba and G. uvula in core JM09-KA11GC and (h) concentration of planktic foraminifera in core GIK23258. (i, j) Mg/Ca-based palaeotemperatures measured in N. pachyderma on the western Svalbard margin (i) core MSM5/5-712-1 (Spielhagen et al. 2011) and (j) core MSM05/5712-2 (Aagaard-Sørensen et al. 2014), (k) flux of N. pachyderma and N. incompta in core JM06-04MC (black line; Zamelczyk et al. 2013) and flux of polar planktic foraminiferal species in core MSM5/5-712-1 (green line; Spielhagen et al. 2011), (I) flux of T. quinqueloba and G. uvula in core JM06-04MC (black line; Zamelczyk et al. 2013) and flux of subpolar planktic foraminiferal species in core MSM5/5-712-1 (green line; Spielhagen et al. 2011), (m) phytoplankton bio-

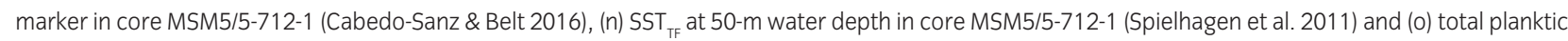
foraminiferal flux in core MSM5/5-712-1 (Werner et al. 2011). Vertical pink bars mark warmer time intervals. For list of records with references, refer to Supplementary Table S1. RWP: Roman Warm Period; DACP: Dark Ages Cold Period; MCA: Medieval Climate Anomaly; LIA: Little Ice Age; RW: Recent Warming. 
indicating a short-lasting pulse of warm Atlantic Water advection (Sarnthein et al. 2003). The differences in productivity signals between the records from off Spitsbergenbanken and Storfjorden Fan can probably be explained by the position of the sea-ice margin and seasonal variation in the extension of the Marginal Ice Zone. The sea-ice margin was likely located further north along the western Svalbard margin, closer to our study site at the time. High planktic foraminiferal flux is reported in core MSM5/5-712-2, suggesting highly productive near-surface to surface waters northwest of Svalbard (Werner et al. 2011; Fig. 7o; Supplementary Table S1). The high surface productivity correlates with a warming of the subsurface water indicated by the $\mathrm{SST}_{\mathrm{Mg} / \mathrm{Ca}}$ based on N. pachyderma (Fig. 7b). Moreover, high productivity at the near-surface to surface in this area is also indicated by a high concentration of phytoplankton biomarkers at about $340 \mathrm{AD}$ and high flux of diatoms at ca. 46-455 AD (Müller et al. 2012; Matul et al. 2018). These conditions are linked to a northward retreat of the sea-ice edge due to strengthened Atlantic Water inflow and/or changes in the atmospheric circulation pattern (Werner et al. 2011; Müller et al. 2012; Matul et al. 2018).

The second warm period at the Storfjorden Fan is recorded at about 900-1400 AD (Fig. 7). Warm SST occurred at about 800-1100 AD in core JM09-KAl IGC from Kveithola Trough and at about 800-1400 AD in core MSM5/5-712-1 from the north-western Svalbard margin and has been associated with the Medieval Climate Anomaly (Spielhagen et al. 2011; Berben et al. 2014; Fig. 7c, n; Supplementary Table S1). The subsurface and near-surface productivity indicated by planktic foraminifera show only a relatively moderate increase at our study site and in other records along the western Barents Sea and Svalbard margin (Fig. 7a, d, f, g, o). Even in northern Storfjorden, where biological production is mainly determined by the extent of the seaice cover and solar radiation, a diminished productivity indicated by a reduction in concentrations of phytoplankton biomarkers has been linked to a reduced seaice cover (Knies et al. 2017).

The two cold periods at 400-900 AD and ca. 1400$1850 \mathrm{AD}$, recorded at Storfjorden Fan, are also identified on the western Svalbard and Barents Sea margin and have been associated with the Dark Ages Cold Period and the Little Ice Age, respectively (Werner et al. 2011; Berben et al. 2014; Werner et al. 2016). They found these intervals to correlate with pronounced changes in the planktic foraminiferal fauna compositions and low planktic foraminiferal flux. The low subsurface and near-surface to surface productivity at Storfjorden Fan during the cold period at 400-900 AD correspond to low primary productivity and low content of phytoplankton biomarkers recorded in northern Storfjorden in core JM10-010GC (Pathirana et al. 2015; Knies et al. 2017), and low concentrations of benthic foraminifera (Rasmussen 8 Thomsen 2015; Fig. 7a, f; Supplementary Table S1). The low productivity is linked to a south-eastward shift of the Marginal Ice Zone associated with extensive sea-ice cover and a reduced inflow of Atlantic Water from the Nordic seas. On the western Svalbard margin, high sea-surface salinity indicates enhanced Atlantic Water influence at about $1600 \mathrm{AD}$ (Werner et al. 2011). As the salinity increase was not accompanied by warmer temperatures, these salinity values were considered erroneous.

At 1400-ca. $1500 \mathrm{AD}$, the moderate to high flux of planktic foraminifera agrees with the high surface productivity recorded by a high flux of cold-water dinocyst assemblages in core JM06-04MC from the western Svalbard margin (Bonnet et al. 2010), but contrasts with a decrease in primary productivity around $1450 \mathrm{AD}$ in the nearby core St20 from the Kveithola Trough on the shelf (Pathirana et al. 2015; Fig. 1; Supplementary Table S1). The interval is referred to as the first half of the Little Ice Age (Bonnet et al. 2010; Pathirana et al. 2015). We speculate that the differences in productivity between the St20 and our site were caused by a highly fluctuating sea-ice margin, with strong seasonal gradients and intense melting at the sea-ice edge due to influence of the warm Atlantic Water, as is observed in the western Barents Sea (e.g., Pathirana et al. 2015). The minimum productivity, but relatively warm surface conditions at ca. 1500-1770 AD at Storfjorden Fan coincided with low fluxes of planktic foraminifera. The warmer conditions are in contrast to the low near-surface temperatures in cores JM06-04MC (Zamelczyk et al. 2013) and MSM5/5-712-2 (Spielhagen et al. 2011; Werner et al. 2011) from the western Svalbard margin and in core JM09-KAllGC from Kveithola Trough (Berben et al. 2014; Fig. 7e-g, k, i, n, o; Supplementary Table S1). The relatively warm conditions at Storfjorden Fan correlate with an increased SST estimated from alkenones $\left(\mathrm{U}^{\mathrm{K}}{ }_{37}\right)$ and reduced sea-ice concentration in spring recorded in the same core MSM5/5-712-1 from the western Svalbard margin (Rueda et al. 2013; Cabedo-Sanz \& Belt 2016). A rapid and short-lasting ice-edge retreat within the Marginal Ice Zone during springs/summers due to the presence of Atlantic Water was most likely responsible for the seasonal warm sea-surface conditions. Nevertheless, the lowest fluxes of all planktic foraminifera with increasing IRD concentration recorded in all compared cores during this time suggest generally enhanced sea-ice cover and harsh sea-surface conditions.

The increase in planktic foraminiferal flux from ca. $1770 \mathrm{AD}$ at our study site correlates with the high surface productivity indicated by high concentration of the 
phythoplankton biomarker brassicasterol from ca. 1750 $\mathrm{AD}$ in core MSM5/5-712-1 from the western Svalbard margin (Fig. 7m; Supplementary Table S1). The high surface productivity has been explained by a change from high seasonal sea-ice cover to a winter ice-edge scenario, with reduced spring sea-ice concentration, at this site (Cabedo-Sanz \& Belt 2016). More sea ice and icebergs after $1850 \mathrm{AD}$, indicated by increased IRD at Storfjorden Fan (Fig. 6i), have been associated with the Little Ice Age from $1860 \mathrm{AD}$ in a record from the western Svalbard margin (Werner et al. 2011). The event is linked to a continuous strengthening of the meridional overturning circulation intensity (Sicre et al. 2008) and increased deep water production in the Norwegian-Greenland Sea.

Studies of planktic and benthic foraminiferal faunas, biomarker and sedimentological reconstructions from the western part of the Nordic seas influenced by the EGC do not depict any prominent cold and warm anomalies (Perner et al. 2015; Andrews et al. 2016). At the shallow Foster Bugt site, north-east Greenland shelf in core PS 2641, the surface conditions described by foraminifera indicate an overall cooling and a large and variable input of meltwater from Greenland from about $800 \mathrm{AD}$ to the present, with markedly increased productivity over the last millennium (Perner et al. 2015; Fig. la; Supplementary Table S1). The cooling trend over the past two millennia has been detected further south, at the southern Greenland margin in core RAPiD-35COM (Moffa-Sánchez \& Hall 2017) and south of Iceland in core RAPiD-17-5P (Moffa-Sánchez et al. 2014). In RAPiD-17-5P, an increasing influence of the EGC and cold surface conditions were recorded over the last millennium by planktic foraminiferal assemblages and $\mathrm{Mg} / \mathrm{Ca}$-based temperature reconstructions from a deep-dwelling planktic foraminiferal species (Moffa-Sánchez et al. 2014; Fig. la; Supplementary Table S1). South of Iceland, in cores RAPiD-21-3K (Sicre et al. 2011) and RAPiD-17-5P (Moffa-Sánchez et al. 2014), clear centennial-scale changes in SST have been linked to climatic events such as the warm Roman Warm Period and cold Little Ice Age (Fig. la; Supplementary Table S1). North of Iceland, apparently subdued temperature variations related to the Little Ice Age and warm Medieval Climate Anomaly were recorded (e.g., Knudsen et al. 2004; Knudsen et al. 2011).

The progressive warming over the last 200 years is considered to be globally synchronous (Neukom et al. 2019 and references herein) and well documented in numerous palaeoproxy studies from the Arctic region (e.g., Kaufman et al. 2009; Majewski et al. 2009; Spielhagen et al. 2011; Werner et al. 2011; Dylmer et al. 2013; Zamelczyk et al. 2013). Some studies consider the last 100 years as the warmest period of the last two millennia (Neukom et al. 2019). In Fram Strait, in core MSM5/5-712-1, fluxes and
SST based on planktic foraminifera show relatively stable temperatures and productivity for most of the past two millennia, and only a rapid increase in the past 100 years that is argued to represent greater advection of Atlantic Water into the Arctic (Spielhagen et al. 2011; Fig. 7k, l, n; Supplementary Table S1). However, the phytoplankton biomarker (brassicasterol) recorded at the same site shows marked variability in productivity throughout the entire studied period (Cabedo-Sanz \& Belt 2016; Fig. 7m; Supplementary Table S1). The SST reconstructions based on dinocyst assemblages indicate a cooling trend with a salinity reduction at the same site over the last 2000 years (Bonnet et al. 2010). The contrasting trends may reflect a habitat bias in the different proxies or, more likely, a bias due to post-depositional dissolution of planktic foraminifera at this location (Zamelczyk et al. 2013; Fig. 7k, l; Supplementary Table S1). At Storfjorden Fan, the SST reconstructions show a distinct warming trend at the near-surface to surface from $1850 \mathrm{AD}$ onwards and surface productivity accompanied the temperature changes at all sites under the influence of warm Atlantic Water (Fig. 7c-f, k-O). Although the subsurface $\mathrm{SST}_{\mathrm{Mg} / \mathrm{Ca}}$-based temperatures indicate a cooling trend, the productivity at the subsurface increased (Fig. 7a, b, k). This can probably be linked to the progressive changes in the net primary production associated with increased temperatures, loss of sea ice and increased phytoplankton production (Arrigo \& van Dijken 2015).

\section{Conclusions}

The major climate anomalies of the past two millennia were reflected in planktic foraminiferal records at Storfjorden Fan, western Svalbard margin, based on the distribution, concentration and flux of species, SST reconstructions by $\mathrm{Mg} / \mathrm{Ca}$, transfer functions and $\delta^{18} \mathrm{O}$ and $\delta^{13} \mathrm{C}$ values of N. pachyderma, T. quinqueloba and G. uvula.

Enhanced fluxes of planktic foraminifera, increased but variable percentages of subpolar species and decreased relative abundances of $N$. pachyderma, along with high mean shell weights, characterized periods at about 21-400 AD, 900-1400 AD and 1850 AD to the present. These periods were linked to a local expression of the northern European climate events, the Roman Warm Period, the Medieval Climate Anomaly and the Recent Warming, respectively. The highest temperatures of the past two millennia occurred during the last 50 years.

Oceanic conditions at about 400-900 AD and 14001850 AD were cold. They were generally characterized by a very low to low flux of planktic foraminifera, a low to moderate relative abundance of the subpolar species and a dominance of the polar species $N$. pachyderma. A very 
low flux of planktic foraminifera, but relative warm SSTs, and increased percentages of subpolar species (T. quinqueloba and G. uvula) were observed at about 1500-1770 AD, which we attribute to a short-lasting amelioration due to the seasonal presence of Atlantic Water. This period was followed by the coldest interval of the past two millennia at approximately 1770-1850 AD, which may be linked to the culmination of the cold climate of the northern European Little Ice Age.

The subsurface (250-75 m) and surface to near-surface (75-0 m) productivity of planktic foraminifera show a generally concurrent response to the climatic and oceanographic development. Moderate to high fluxes and concentrations of planktic foraminifera characterized warm periods, and low fluxes and concentrations of planktic foraminifera characterized cold periods. The highest planktic productivity indicated by very high, but variable, planktic foraminiferal flux and concentration occurred at about 1300-1500 AD, 1750-1860 AD and over the past 50 years or so. These periods likely represent a general amelioration of conditions from years with sea-ice cover to years with a fluctuating summer ice margin.

A close link between the shell weights, the preservation of planktic foraminifera and Atlantic Water presence during the past 2000 years, except the last 50 years, implies that the main factor controlling the calcification rate of planktic foraminifera is the carbonate chemistry state $\left(\left[\mathrm{CO}_{3}{ }^{2-}\right]\right.$ and $\left.\Omega_{\mathrm{Ca}}\right)$ of the Atlantic Water.

Our reconstructed $\mathrm{SST}_{\mathrm{TF}}$ correlates with atmospheric temperatures for the last 162 years, suggesting a high reliability of our SST reconstruction based on the planktic foraminiferal data for the past 2000 years and further confirms that the warming of the last 50 years is a well-established occurrence within Fram Strait.

Comparison to other records from the western Svalbard margin and western Barents Sea based on different productivity and climate proxies (planktic foraminifera, dinocysts, alkenones) show temporary inconsistencies. These inconsistencies have been reported previously and can be attributed to the local variability of the seaice margin, the response of biological productivity to the variability and the possible habitat and/or preservation biases that each proxy represents.

\section{Acknowledgements}

The authors thank the captains and crews of RV Jan Mayen/Helmer Hanssen and engineers S. Iversen and B.R. Olsen for technical assistance. T. Dahl is thanked for laboratory assistance and T. Grytå for creating the area map. The authors thank B. Sternal and W. Szczuciński for helpful suggestions and discussions of interpretation of the ${ }^{210} \mathrm{~Pb}$ and ${ }^{137} \mathrm{Cs}$ dating. Jessica Green corrected the English language. The authors also thank Dr Elena Ivanova, anonymous Reviewer \#2 and Section Editor Robert Spielhagen for their valuable comments, which greatly improved the manuscript.

\section{Funding}

The study was carried out within the framework of the project Effects of Ocean Chemistry Changes on Planktic Foraminifera in the Fram Strait: Ocean Acidification from Natural to Anthropogenic Changes, funded by the Research Council of Norway (project no. 216538), the Centre for Arctic Gas Hydrate, Environment and Climate, supported by the Research Council of Norway (project no. 223259) and UiT. This study was also supported by the Ocean Acidification flagship within the Fram-High North Centre for Climate and the Environment, Norway. In addition, the publication was supported by the publication fund of UiT.

\section{Disclosure statement}

The authors report no conflict of interest.

\section{References}

Aagaard-Sørensen S., Husum K., Hald M., Marchitto T. \& Godtliebsen F. 2014. Sub sea surface temperatures in the polar North Atlantic during the Holocene: planktic foraminiferal Mg/Ca temperature reconstructions. The Holocene 24, 93-103, doi: 10.1177/0959683613515730.

Abram N., McGregor H., Tierney J., Evans M.N., McKay N.P., Kaufman D.S. \& the PAGES 2k Consortium 2016. Early onset of industrial-era warming across the oceans and continents. Nature 536, 41 1-418, doi: 10.1038/nature 19082.

Alexander V. 1980. Interrelationships between the seasonal sea ice and biological regimes. Cold Regions Science and Technology 2, 157-178, doi: 10.1016/0165-232X(80)90072-5.

Andresen C., Hansen M., Seidenkrantz M.-S., Jennings A., Knudsen M., Nørgaard-Pedersen N., Larsen N.K., Kuijpers A. \& Pearce C. 2013. Mid- to late-Holocene oceanographic variability on the southeast Greenland shelf. The Holocene 23, 167-178, doi: 10.1177/0959683612460789.

Andrews J.T., Stein R., Moros M. \& Perner K. 2016. Late Quaternary changes in sediment composition on the NE Greenland margin $\left(\sim 73^{\circ} \mathrm{N}\right)$ with a focus on the fjords and shelf. Boreas 45, 381-397, doi: 10.1111/bor.12169.

Arrigo K.R. \& van Dijken G.L. 2015. Continued increases in Arctic Ocean primary production. Progress in Oceanography 136, 60-70, doi: 10.1016/j.pocean.2015.05.002.

Barker S., Greaves M. \& Elderfield H. 2003. A study of cleaning procedures used for foraminiferal $\mathrm{Mg} / \mathrm{Ca}$ paleothermometry. Geochemistry, Geophysics, Geosystems 4, article no. 8407, doi: 10.1029/2003GC000559. 
Bauch D., Carsens J. \& Wefer G. 1997. Oxygen isotope composition of living Neogloboquadrina pachyderma (sin.) in the Arctic Ocean. Earth and Planetary Science Letters 146, 47-58, doi: 10.1016/S0012-821X(96)00211-7.

Bé A.H.W. \& Tolderlund D.S. 1971. Distribution and ecology of living planktonic foraminifera in surface waters of the Atlantic and Indian Oceans. In B.M. Funnell \& W.R. Riedel (eds.): The micropaleontology of the oceans. Pp. 105-149. Cambridge: Cambridge University Press.

Bemis B.E., Spero H.J., Lea D.W. \& Bijma J. 2000. Temperature influence on the carbon isotopic composition of Globigerina bulloides and Orbulina universa (planktonic foraminifera). Marine Micropaleontology 38, 213-228, doi: 10.1016/S0377-8398(00)00006-2.

Berben S.M.P., Husum K., Cabedo-Sanz P. \& Belt S.T. 2014. Holocene sub-centennial evolution of Atlantic Water inflow and sea ice distribution in the western Barents Sea. Climate of the Past 10, 181-198, doi: 10.5194/ cp-10-181-2014.

Berben S.M.P., Husum K., Navarro-Rodriguez A., Belt S.T. \& Aagard-Sørensen S. 2017. Semi-quantitative reconstruction of early to late Holocene spring and summer sea ice conditions in the northern Barents Sea. Journal of Quaternary Science 32, 587-603, doi: 10.1002/jqs.2953.

Berger W.H. 1970. Planktonic foraminifera-selective solution and the lysocline. Marine Geology 8, 111-138, doi: 10.1016/0025-3227(70)90001-0.

Berger W.H., Bonneau M.C. \& Parker F.L. 1982. Foraminifera on the deep-sea floor: lysocline and dissolution rate. Oceanologia Acta 5, 249-258.

Berkeley Earth. 2019. Land and ocean summary, land + ocean data. Accessed on the internet at http://berkeleyearth.org/ archive/land-and-ocean-data/\#section-0-7 on 1 June 2019.

Beszczynska-Möller A., Fahrbach E., Schauer U. \& Hansen E. 2012. Variability in Atlantic water temperature and transport at the entrance to the Arctic Ocean, 1997-2010. ICES Journal of Marine Science 69, 852-863, doi: 10.1093/icesjms/ fss0 06 .

Blindheim J., Borovkov V., Hansen B., Malmberg S.A, Turrell W.R. \& Østerhus S. 2000. Upper layer cooling and freshening in the Norwegian Sea in relation to atmospheric forcing. Deep-Sea Research Part I 47, 655-680, doi: 10.1016/ S0967-0637(99)00070-9.

Boltovskoy E., Boltovskoy D., Correa N. \& Brandini F. 1996. Planktic foraminifera from the southwestern Atlantic $\left(30^{\circ}-60^{\circ} \mathrm{S}\right)$ : species-specific patterns in the upper $50 \mathrm{~m}$. Marine Micropaleontology 28, 53-72, doi: 10.1016/0377-8398(95)00076-3.

Bonnet S., de Vernal A., Hillaire-Marcel C., Radi T. \& Husum K. 2010. Variability of sea surface temperature and seaice cover in the Fram Strait over the last two millennia. Marine Micropaleontology 74, 59-74, doi: 10.1016/j. marmicro.2009.12.001.

Cabedo-Sanz P. \& Belt S.T. 2016. Seasonal sea ice variability in eastern Fram Strait over the last 2000 years. Arktos 2, article no. 22, doi: 10.1007/s41063-016-0023-2.

Carroll J. \& Lerche I. 2003. Sedimentary processes: quantification using radionuclides. Amsterdam: Elsevier.
Carstens J., Hebbeln D. \& Wefer G. 1997. Distribution of planktic foraminifera at the ice margin in the Arctic (Fram Strait). Marine Micropaleontology 29, 257-269, doi: 10.1016/ S0377-8398(96)00014-X.

Chierici M., Fransson A., Lansard B., Miller L.A., Mucci A., Shadwick E., Thomas H., Tremblay J.-E. \& Papakyriakou T. 2011 . The impact of biogeochemical processes and environmental factors on the calcium carbonate saturation state in the Circumpolar Flaw Lead in the Amundsen Gulf, Arctic Ocean. Journal of Geophysical Research-Oceans 116, C00G09, doi: 10.1029/2011JC007184.

Conan S.M.H., Ivanova E.M. \& Brummer G.J.A. 2002. Quantifying carbonate dissolution and calibration of foraminiferal dissolution indices in the Somali Basin. Marine Geology 182, 325-349, doi: 10.1016/S0025-3227(01)00238-9.

Cota G.F. \& Sullivan C.W. 1990. Photoadaptation, growth and production of bottom ice algae in the Antarctic. Journal of Phycology 26, 399-411, doi: 10.1111/j.0022-3646.1990.00399.x.

Dickson A.G. 1990. Standard potential of the $(\mathrm{AgCl}(\mathrm{s}) 11 / 2 \mathrm{H} 2$ (g) $5 \mathrm{Ag}(\mathrm{s}) 1 \mathrm{HCl}(\mathrm{aq})$ ) cell and the dissociation constant of bisulfate ion in synthetic sea water from 273.15 to 318.15 K. Journal of Chemical Thermodynamics 22, 113-127.

Dickson A.G. \& Millero F.J. 1987. A comparison of the equilibrium constants for the dissociation of carbonic acid in seawater media. Deep Sea Research 34, 1733-1743, doi: 10.1016/0198-0149(87)90021-5.

Dickson A.G., Sabine C.L. \& Christian J.R. 2007. Guide to best practices for ocean $\mathrm{CO}^{2}$ measurements. PICES Special Publication 3. IOCCP Report 8. Sidney, BC: North Pacific Marine Science Organization.

Dickson R.R., Meincke J. \& Rhines P. 2008. A general introduction. In R.R. Dickson et al. (eds.): Arctic-Subarctic ocean fluxes: defining the role of the northern seas in climate. Pp. 1-12. Dordrecht: Springer.

Duplessy J.-C. 1978. Isotope studies. In J. Gribbin (ed.): Climatic change. Pp. 46-67. London: Cambridge University Press.

Dylmer C.V., Giraudeau J., Eynaud F., Husum K. \& de Vernal A. 2013. Northward advection of Atlantic water in the eastern Nordic seas over the last $3000 \mathrm{yr}$. Climate of the Past 9, 1505-1518, doi: 10.5194/cp-9-1505-2013.

Ehrmann W.U. \& Thiede J. 1985. History of Mesozoic and Cenozoic sediments fluxes to the North Atlantic Ocean. Stuttgart: E. Schweizerbart'sche Verlagsbuchhandlung.

Ellingsen I., Dalpadado P., Slagstad D. \& Loeng H. 2008. Impact of climatic change on the biological production in the Barents Sea. Climate Change 87, 155-175, doi: 10.1007/ s10584-007-9369-6.

Espitalié J., Laporte J.L., Madec M., Marquis F., Leplat P., Paulet J. \& Boutefeu A. 1977. Méthode rapide de characterisation des roches-mere, de leur potential petrolier et de leur degre d'évolution. (Rapid method of characterization of parent rocks, their petroleum potential and their degree of evolution.) Revue de l'Institute Francais du Petrole 32, 23-42.

Feyling-Hanssen R.W., Jorgensen J.A., Knudsen K.L. \& Anderson A.L. 1971. Late Quaternary foraminifera from Vendsyssel, Denmark and Sandnes, Norway. Bulletin of the Geological Society of Denmark 21, 67-317. 
Fransson A., Chierici M., Miller L.A., Carnat G., Thomas H., Shadwick E., Pineault S. \& Papakyriakou T.M. 2013. Impact of sea-ice processes on the carbonate system and ocean acidification state at the ice-water interface of the Amundsen Gulf, Arctic Ocean. Journal of Geophysical ResearchOceans 118, 7001-7023, doi: 10.1002/2013JC009164.

Gosselin M., Legendre L., Therriault J.C. \& Demers S. 1990. Light and nutrient limitation of sea ice microalgae (Hudson Bay, Canadian Arctic). Journal of Phycology 26, 220232, doi: 10.1111/j.0022-3646.1990.00220.x.

Grøttheim S. 1999. Artificial radionuclides in the Northern European Marine Environment in 1995. Distribution of plutonium, americium and radiocaesium in seawater and sediments. Cand. scient. thesis, Department of Biology, Section of Marine Zoology and Marine Chemistry, University of Oslo.

Grove J.M. 2004. Little ice ages: ancient and modern. 2 vols. London: Taylor \& Francis.

Hathorne E.C., Gagnon A., Felis T., Adkins J., Asami R., Boer W., Caillon N., Case D., Cobb K.M., Douville E., deMenocal P., Eisenhauer A., Garbe-Schönberg D., Geibert W., Inoue M., Kawahata H., Kölling M., Cornec F.L., Linsley B.K., McGregor H.V., Montagna P., Nurhati I.S., Quinn T.M., Raddatz J., Rebaubier H., Robinson L., Sadekov A., Sherrell R., Sinclair D., Tudhope A.W., Wei G., Wong H., Wu H.C. \& You C.-F. 2013. Interlaboratory study for coral Sr/ $\mathrm{Ca}$ and other element/Ca ratio measurements. Geochemistry, Geophysics, Geosystems 14, 3730-3750, doi: 10.1002/ ggge. 20230.

Hemleben C., Spindler M. \& Anderson O.R. 1989. Modern planktonic foraminifera. New York: Springer.

Hoff U., Rasmussen T.L., Stein R.M., Ezat M. \& Fahl K. 2016. Sea ice and millennial-scale climate variability in the Nordic seas 90 Ka to present. Nature Communication 7, article no. 12247, doi: 10.1038/ncomms 12247.

Hop H., Falk-Petersen S., Svendsen H., Kwaśniewski S., Pavlov V., Pavlova O. \& Søreide J.E. 2006. Physical and biological characteristics of the pelagic system across Fram Strait to Kongsfjorden. Progress in Oceanography 71, 182-231, doi: 10.1016/j.pocean.2006.09.007.

Huber R., Meggers H., Baumann K.H. \& Henrich R. 2000. Recent and Pleistocene carbonate dissolution in sediments of the Norwegian-Greenland Sea. Marine Geology 165, 123136, doi: 10.1016/S0025-3227(99)00138-3.

Hulot V. 2015. Variabilité spatiale et structurelle des communautés du phytoplancton et de foraminiferes planctoniques à l'entrée de la Mer de Barents. (Spatial and structural variability of phytoplankton and planktonic foraminifera communities at the entrance to the Barents Sea.) Msc thesis, Université de Bretagne Occidentale.

Husum K. \& Hald M. 2012. Arctic planktic foraminiferal assemblages: implications for subsurface temperature reconstructions. Marine Micropaleontology 96-97, 38-47, doi: 10.1016/j.marmicro.2012.07.001.

Imbrie J. \& Kipp N.G. 1971. A new micropaleontological method for quantitative paleoclimatology: application to a late Pleistocene Caribbean core. In K.K. Turekian (ed.): Late Cenozoic glacial ages. Pp. 71-147. New Haven, CT: Yale University Press.
Inoue M., Nohara M., Okai T., Suzuki A. \& Kawahata H. 2004. Concentrations of trace elements in carbonate reference materials Coral JCp-1 and Giant Clam JCt-1 by inductively plasma-mass spectrometry. Geostandards and Geoanalytical Research 28, 411-416, doi: $10.1111 / \mathrm{j} .1751$ 908X.2004.tb00759.x.

Isachsen P.E., Mauritzen C. \& Svendsen H. 2007. Dense water formation in the Nordic seas diagnosed from sea surface buoyancy fluxes. Deep-Sea Research I 54, 22-41, doi: 10.1016/j.dsr.2006.09.008.

Jiang H., Seidenkrantz M.-S., Knudsen K.L. \& Eiriksson J. 2002. Late-Holocene summer sea-surface temperatures based on a diatom record from the north Icelandic shelf. Holocene 12, 137-147, doi: 10.1191/0959683602hl529rp.

Johannessen T., Jansen E., Flatøy A. \& Ravelo A.C. 1994. The relationship between surface water masses, oceanographic fronts and paleoclimatic proxies in surface sediments of the Greenland, Iceland, Norwegian seas. NATO ASI Series I, 61-86.

Juggins S. 2010. Software for ecological and palaeoecological data analysis and visualization. C2, version 1.6.6. University of Newcastle, Newcastle upon Tyne, UK.

Kaufman D.S., Schneider D.P., McKay N.P., Ammann C.M., Bradley R.S., Briffa K.R., Miller G.H., Otto-Bliesner B.L., Overpeck J.T., Vinther B.M. \& Arctic Lakes 2k Project Members 2009. Recent warming reverses long-term Arctic cooling. Science 325, 1236-1239, doi: 10.1126/ science. 1173983.

Knies J., Pathirana I., Cabedo-Sanz P., Banica A., Fabian K, Rasmussen T.L., Forwick M. \& Belt S. 2017. Sea-ice dynamics in an Arctic coastal polynya during the past 6500 years. Arktos 3, article no. 1, doi: 10.1007/s41063-016-0027-y.

Knudsen K.L. 1998. Foraminiferer i Kvartær stratigrafi: laboratorie og fremstillingsteknik samt udvalgte eksempler. (Foraminifera in Quaternary stratigraphy: laboratory and preparation techniques as well as selected examples.) Geologisk Tidsskrift 3, 1-25.

Knudsen K.L., Jiang J., Jansen E., Eiríksson J., Heinemeier J. \& Seidenkrantz M.-S. 2004. Environmental changes off North Iceland during the deglaciation and the Holocene: foraminifera, diatoms and stable isotopes. Marine Micropaleontology 50, 273-305, doi: 10.1016/ S0377-8398(03)00075-6.

Knudsen M.F, Seidenkrantz M.-S., Jacobsen B.H. \& Kuijpers A. 2011. Tracking the Atlantic multidecadal oscillation through the last 8,000 years. Nature Communications 2, article no. 178, doi: 10.1038/ncomms1186.

Kozdon R., Eisenhauer A., Weinelt M., Meland M.Y. \& Nürnberg D. 2009. Reassessing Mg/Ca temperature calibrations of Neogloboquadrina pachyderma (sinistral) using paired $\delta^{44} /{ }^{40} \mathrm{Ca}$ and $\mathrm{Mg} / \mathrm{Ca}$ measurements. Geochemistry, Geophysics, Geosystems 10, article no. 3, doi: 10.1029/2008GC002169.

Kunzendorf H. \& Larsen B. 2002. A 200-300 year cyclicity in sediment deposition in the Gotland Basin, Baltic Sea, as deduced from geochemical evidence. Applied Geochemistry 17, 29-38, doi: 10.1016/S0883-2927(01)00088-9.

Lamb H.H. 1977. Climate: present, past and future. Vol. 2. Climatic history and the future. London: Methuen. 
Le J.N. \& Thunell R.C. 1996. Modelling planktic foraminiferal assemblage changes and application to sea surface temperature estimation in the western equatorial Pacific Ocean. Marine Micropaleontology 28, 211-229, doi: 10.1016/0377-8398(96)00009-6.

Lischka S., Stange P. \& Riebesell U. 2018. Response of pelagic calcifiers (Foraminifera, Thecosomata) to ocean acidification during oligotrophic and simulated up-welling conditions in the subtropical North Atlantic off Gran Canaria. Frontiers in Marine Science 5, article no. 379, doi: 10.3389/ fmars.2018.00379.

Loeng H. 1991. Features of the physical oceanographic conditions of the Barents Sea. Polar Research 10, 5-18, doi: 10.3402/polar.v10il.6723.

Lombard F., da Rocha R.E., Bijma J. \& Gattuso J.-P. 2010. Effect of carbonate ion concentration and irradiance on calcification in planktonic foraminifera. Biogeoscience 7, 247-255, doi: 10.5194/bg-7-247-2010.

Lutze G.F. \& Altenbach A. 1991. Technik und Signifikanz der Lebendfarbung benthischer Foraminiferen mit Bengalrot. (Technique and significance of rose Bengal staining benthic foraminifera.) Geologisches Jahrbuch A 128, 251-265.

Majewski W., Szczuciński W. \& Zajączkowski M. 2009. Interactions of Arctic and Atlantic water-masses and associated environmental changes during the last millennium, Hornsund (SW Svalbard). Boreas 38, 529-544, doi: $10.1111 / j .1502-3885.2009 .00091 . x$.

Mangerud J., Bondevik S., Gulliksen S., Hufthammer A.K. \& Høisæter T. 2006. Marine ${ }^{14} \mathrm{C}$ reservoir ages for 19 th century whales and molluscs from the North Atlantic. Quaternary Science Reviews 25, 3228-3245, doi: 10.1016/j. quascirev.2006.03.010.

Manno C., Morata N. \& Bellerby R. 2012. Effect of ocean acidification and temperature increase on the planktonic foraminifer Neogloboquadrina pachyderma (sinistral). Polar Biology 35, 1311-1319, doi: 10.1007/ s00300-012-1174-7.

Matul A., Spielhagen F.R, Kazarina G., Kruglikova S., Dmitrenko O. \& Mohan R. 2018. Warm-water events in the eastern Fram Strait during the last 2000 years as revealed by different microfossil groups. Polar Research 37, article no. 1540243, doi: 10.1080/17518369.2018.1540243.

McGregor H.V., Evans M.N., Goosse H., Leduc G., Martrat B., Addison J.A., Mortyn G., Oppo D.W., Seidenkrantz M.-S., Sicre M.-A., Phipps S.J., Selvaraj K., Thirumalai K., Filipsson H.L. \& Ersek V. 2015. Robust global ocean cooling trend for the pre-industrial Common Era. Nature Geoscience 8, 671-677, doi: 10.1038/ngeo2510.

McKee B.A., Nittrouer C.A. \& DeMaster D.J. 1983. Concepts of sediment deposition and accumulation applied to the continental shelf near the mouth of the Yangtze River. Geology 11, 631-633, doi: 10.1130/0091-7613(1983)11<631:COSDAA>2.0.CO;2.

Mehrbach C., Culberson C.H., Hawley J.E. \& Pytkowicx R.M. 1973. Measurement of the apparent dissociation constants of carbonic acid in seawater at atmospheric pressure. Limnology and Oceanography 8, 897-907, doi: 10.4319/ lo.1973.18.6.0897.
Michel C., Legendre L., Demers S. \& Therriault J.C. 1988. Photoadaptation of sea ice microalgae in springtime: photosynthesis and carboxylating enzymes. Marine Ecology Progress Series 50, 177-185, 10.3354/meps050177.

Moffa-Sánchez P., Born A., Hall I.R., Thornalley D.J.R. \& Barker S. 2014. Solar forcing of North Atlantic surface temperature and salinity over the past millennium. Nature Geoscience 7, 275-278, doi: 10.1038/ngeo2094.

Moffa-Sánchez P. \& Hall I.R. 2017. North Atlantic variability and its links to European climate over the last 3000 years. Nature Communication 8, article no. 1726, doi: 10.1038/ s41467-017-01884-8.

Moffa-Sánchez P., Moreno-Chamarro E., Reynolds D.J., Ortega P., Cunningham L., Swingedouw D., Amrhein D.E., Halfar J., Jonkers L., Jungclaus J.H, Perner K., Wanamaker A. \& Yeager S. 2019. Variability in the northern North Atlantic and Arctic oceans across the last two millennia: a review. Paleoceanography and Paleoclimatology 34, 1399-1436, doi: 10.1029/2018PA003508.

Mucci A.1983. The solubility of calcite and aragonite in seawater at various salinities, temperatures and at one atmosphere pressure. American Journal of Science 283, 781-799, doi: 10.2475/ajs.283.7.780.

Müller J., Werner K., Stein R., Fahl K., Moros M. \& Jansen E. 2012. Holocene cooling culminates in sea-ice oscillations in Fram Strait. Quaternary Science Reviews 47, 1-14, doi: 10.1016/j.quascirev.2012.04.024.

Neukom R., Steiger N., Gómez-Navarro J.J., Wang J. \& Werner J.P. 2019. No evidence for globally coherent warm and cold periods over the preindustrial Common Era. Nature 571, 550-554, doi: 10.1038/s41586-019-1401-2.

Nürnberg D. 1995. Magnesium in tests of Neogloboquadrina pachyderma sinistral from high northern and southern latitudes. Journal of Foraminiferal Research 25, 350-368, doi: 10.2113/gsjfr.25.4.350.

Olsen A., Omar A.M., Jeansson E., Anderson L.G. \& Bellerby R.G.J. 2010. Nordic seas transit time distributions and anthropogenic $\mathrm{CO}_{2}$. Journal of Geophysical Research-Oceans 115, C05005, doi: 10.1029/2009JC005488.

Owrid G., Socal G., Civitarese G., Luchetta A., Wiktor J., Nöthig E.M., Andreassen I., Schauer U. \& Strass V. 2000. Spatial variability of phytoplankton, nutrients and new production estimates in the waters around Svalbard. Polar Research 19, 155-171, doi: 10.1111/j.1751-8369.2000. tb00340.x.

Pados T. \& Spielhagen R.F. 2014. Species distribution and depth habitat of recent planktic foraminifera in Fram Strait, Arctic Ocean. Polar Research 33, article no. 22483, doi: 10.3402/polar.v33.22483.

Pados T., Spielhagen R.F., Bauch D., Meyer H. \& Segl M. 2015. Oxygen and carbon isotope composition of modern planktic foraminifera and near-surface waters in the Fram Strait (Arctic Ocean)—a case study. Biogeosciences 12, 17331752, doi: 10.5194/bg-12-1733-2015.

Parker F.L. 1962. Planktonic foraminiferal species in Pacific sediments. Micropaleontology 8, 219-254.

Pathirana I., Knies J., Felix M., Mann U. \& Ellingsen I. 2015. Middle to late Holocene paleoproductivity reconstructions 
for the western Barents Sea: a model-data comparison. Arktos 1, article no. 20, doi: 10.1007/s41063-015-0002-z.

Pawłowska J., Zajączkowski M., Łącka M., Lejzerowicz F., Esling P. \& Pawłowski J. 2016. Palaeoceanographic changes in Hornsund Fjord (Spitsbergen, Svalbard) over the last millennium: new insights from ancient DNA. Climate of the Past 12, 1459-1472, doi: 10.5194/cp-12-1459-2016.

Peeters F.J.C., Brummer G.A. \& Ganssen G. 2002. The effect of upwelling on the distribution and stable isotope composition of Globigerina bulloides and Globigerinoides ruber (planktic foraminifera) in modern surface waters of the NW Arabian Sea. Global and Planetary Change 34, 269-291, doi: 10.1016/S0921-8181(02)00120-0.

Perner K., Moros M., Lloyd J.M., Jansen E. \& Stein R. 2015. Mid to late Holocene strengthening of the East Greenland Current linked to warm subsurface Atlantic water. Quaternary Science Reviews 129, 296-307, doi: 10.1016/j. quascirev.2015.10.007.

Peterson L.C. \& Prell W.L. 1985. Carbonate dissolution in recent sediments of the eastern equatorial Indian Ocean: preservation patterns and carbonate loss above the lysocline. Marine Geology 64, 259-290, doi: 10.1016/0025-3227(85)90108-2.

Petró S.M., Pivel M.A.G. \& Coimbra J.C. 2018. Foraminiferal solubility rankings: a contribution to the search for consensus. Journal of Foraminiferal Research 48, 301-313, doi: 10.2113 /gsjfr.48.4.301.

Pierrot D., Lewis E. \& Wallace D.W.R. 2006. MS Excel program developed for $\mathrm{CO}^{2}$ system calculations, ORNL/CDIAC-105. Oak Ridge, TN: Carbon Dioxide Information Analysis Center, Oak Ridge National Laboratory, U.S. Department of Energy.

Reigstad M., Wassmann P., Riser C.W., Øygarden S. \& Rey F. 2002. Variations in hydrography, nutrients and chlorophyll a in the marginal ice-zone and the central Barents Sea. Journal of Marine Systems 38, 9-29, doi: 10.1016/ S0924-7963(02)00167-7.

Rasmussen T.L. \& Thomsen E. 2015. Paleoceanographic development in Storfjorden, Svalbard, during the deglaciation and Holocene: evidence from benthic foraminiferal records. Boreas 44, 24-44, doi: 10.1111 /bor.12098.

Rasmussen T.L., Thomsen E., Skirbekk K., Ślubowska-Woldengen M., Klitgaard Kristensen D. \& Koç N. 2014. Spatial and temporal distribution of Holocene temperature maxima in the northern Nordic seas: interplay of Atlantic, Arctic and Polar water masses. Quaternary Science Reviews 92, 280-291, doi: 10.1016/j.quascirev.2013.10.034.

Rasmussen T.L., Thomsen E., Troelstra S.R., Kuijpers A. \& Prins M. 2003. Millennial scale glacial variability versus Holocene stability: changes in planktic and benthic foraminifera faunas and ocean circulation in the North Atlantic during the last 60,000 years. Marine Micropaleontology 47, 143-176, doi: 10.1016/S0377-8398(02)00115-9.

Rebotim A., Voelker A.H.L., Jonkers L., Waniek J.J., Meggers H., Schiebel R., Fraile I., Schulz M. \& Kucera M. 2017. Factors controlling the depth habitat of planktonic foraminifera in the subtropical eastern North Atlantic. Biogeosciences 14, article no. 827, doi: 10.5194/bg-14-827-2017.
Reimer P.J., Bard E., Bayliss A., Beck J.W., Blackwell P.P., Ramsey C.B., Buck C.E., Cheng H., Edwards R.L., Friedrich M., Grootes P.M., Guilderson T.P., Haflidason H., Hajdas I., Hatté C., Heaton T.J., Hoffmann D.L., Hogg A.G., Hughen K.A., Kaiser K.F., Kromer B., Manning S.W., Niu M., Reimer R.W., Richards D.A., Scott E.M., Southon J.R., Staff R.A., Turney C.S.M. \& van der Plicht J. 2013. IntCall 3 and Marine 13 radiocarbon age calibration curves, 0-50,000 years cal BP. Radiocarbon 55, 1869-1887, doi: $10.2458 /$ azu_js_rc.55.16947.

Rhines P., Häkkinen S. \& Josey S.A. 2008. Is oceanic heat transport significant in the climate system? In R.R. Dickson et al. (eds.): Arctic-Subarctic ocean fluxes: defining the role of the northern seas in climate. Pp. 87-109. Dordrecht: Springer.

Robbins J.A. \& Edgington D.N. 1975. Determination of recent sedimentation rates in Lake Michigan using $\mathrm{Pb}-210$ and Cs-137. Geochimica et Cosmochimica Acta 39, 285-304, doi: 10.1016/0016-7037(75)90198-2.

Rudels B. 1996. The thermohaline circulation in the Arctic Ocean and in the Greenland Sea. Philosophical Transactions of the Royal Society London A352, 287-299, doi: 10.1098/ rsta.1995.0071.

Rudels B., Meyer R., Fahrbach E., Ivanov V.V., Østerhus S., Quadfasel D., Schauer U., Tverberg V. \& Woodgate R.A. 2000. Water mass distribution in Fram Strait and over the Yermak Plateau in summer 1997. Annals of Geophysics 18, 687-705, doi: 10.1007/s00585-000-0687-5.

Rueda G., Fietz S. \& Rosell-Melé A. 2013. Coupling of air and sea surface temperatures in the eastern Fram Strait during the last 2000 years. Holocene 23, 692-698, doi: 10.1177/0959683612470177.

Russell A.D., Hönisch B., Spero H.J. \& Lea D.W. 2004. Effects of seawater carbonate ion concentration and temperature on shell $\mathrm{U}, \mathrm{Mg}$, and $\mathrm{Sr}$ in cultured planktonic foraminifera. Geochimica et Cosmochimica Acta 68, 4347-4361, doi: 10.1016/j.gca.2004.03.013.

Sakshaug E. 1997. Biomass and productivity distributions and their variability in the Barents Sea. ICES Journal of Marine Science 54, 341-350, doi: 10.1006/jmsc.1996.0170.

Sakshaug E. \& Slagstad D. 1992. Sea ice and wind: effects on primary productivity in the Barents Sea. Atmosphere-Ocean 30, 579-591, doi: 10.1080/07055900.1992.9649456.

Sarnthein M., Van Kreveld S., Erlenkeuser H., Grootes P.M., Kucera M., Pflaumann U. \& Schulz M. 2003. Centennial-to-millennial-scale periodicities of Holocene climate and sediment injections off the western Barents shelf, $75^{\circ} \mathrm{N}$. Boreas 32, 447-461, doi: 10.1111/j.1502-3885.2003. tb01227.x.

Sarnthein M. \& Werner K. 2017. Early Holocene planktic foraminifers record species-specific ${ }^{14} \mathrm{C}$ reservoir ages in Arctic Gateway. Marine Micropaleontology 135, 45-55, doi: 10.1016/j.marmicro.2017.07.002.

Schiebel R., Spielhagen R.F., Garnier J., Hagemann J., Howa H., Jentzen A., Martínez-Garcia A., Meilland J., Michel E., Repschläger J., Salter I., Yamasaki M. \& Haug G. 2017. Modern planktic foraminifers in the high-latitude ocean. Marine Micropaleontology 136, 1-13, doi: 10.1016/j. marmicro.2017.08.004. 
Sicre M.-A., Hall I.R., Mignot J., Khodri M., Ezat U., Truong M.-X., Eiríksson J. \& Knudsen K.L. 2011. Sea surface temperature variability in the subpolar Atlantic over the last two millennia. Paleoceanography 26, PA4218, doi: 10.1029/2011PA002169.

Sicre M.-A., Jacob J., Ezat U., Rousse S., Kissel C., Yiou P., Eiríksson J., Knudsen K.-L., Jansen E. \& Turon J.-L. 2008. Decadal variability of sea surface temperatures off north Iceland over the last 2000 years. Earth and Planetary Science Letters 268, 137-142, doi: 10.1016/j.epsl.2008.01.011.

Simstich J., Sarnthein M. \& Erlenkeuser H. 2003. Paired delta ${ }^{18} \mathrm{O}$ signals of Neogloboquadrina pachyderma (s) and Turborotalita quinqueloba show thermal stratification structure in Nordic seas. Marine Micropaleontology 48, 107-125, doi: 10.1016/S0377-8398(02)00165-2.

Shackleton N.J. 1974. Attainment of isotopic equilibrium between ocean water and the benthonic foraminifera genus Uvigerina: isotopic changes in the ocean during the last glacial. Centre National de la Recherche Scientifique Colleagues Internationeau 219, 203-209.

Skogseth R., Smedsrud L.H., Nilsen F. \& Fer I. 2008. Observations of hydrography and downflow of brine-enriched shelf water in the Storfjorden polynya, Svalbard. Journal of Geophysical Research-Oceans 113, C08049, doi: 10.1029/2007JC004452.

Smith W.O. Jr., Baumann M.E.M., Wilson D.L. \& Aletsee L. 1987. Phytoplankton biomass and productivity in the Marginal Ice Zone of the Fram Strait during summer 1984. Journal of Geophysical Research-Oceans 92, 6777-6786, doi: 10.1029/JC092iC07p06777.

Smith W.O. \& Sakshaug E. 1990. Polar phytoplankton. In W.O. Smith Jr. (ed.): Polar oceanography. Part B. Chemistry, biology and geology. Pp. 477-525. New York: Academic Press.

Spero H.J., Bijma J., Lea D.W. \& Bemis B.E. 1997. Effect of seawater carbonate concentration on foraminiferal carbon and oxygen isotopes. Nature 390, 497-500.

Spielhagen R.F., Werner K., Aagaard-Sørensen S., Zamelczyk K., Kandiano E., Budeus G., Husum K., Marchitto T. \& Hald M. 2011. Enhanced modern heat transfer to the Arctic by warm Atlantic water. Science 331, 450-453, doi: 10.1126/science.1197397.

Stuiver M. \& Reimer P.J. 1993. Extended ${ }^{14} \mathrm{C}$ data base and revised CALIB $3.0{ }^{14} \mathrm{C}$ age calibration program. Radiocarbon 35, 215-230, doi: 10.1017/S0033822200013904.

Telford R.J. \& Birks H.J.B. 2005. The secret assumption of transfer functions: problems with spatial autocorrelation in evaluating model performance. Quaternary Science Reviews 24, 2173-2179, doi: 10.1016/j.quascirev.2005.05.001.

Thunell R. \& Honjo S. 1981. Calcite dissolution and the modification of planktonic foraminiferal assemblages. Marine Micropaleontology 6, 169-182, doi: 10.1016/0377-8398(81)90004-9.

Tremblay J.-E. \& Gagon J. 2009. The effects of irradiance and nutrient supply on the productivity of Arctic waters: a perspective on climate change. In J.C.J. Nihoul \& A.G. Kostianoy (eds.): Influence of climate change on the changing Arctic and sub-Arctic conditions. Pp. 73-93. Dordrecht: Springer.
Walczowski W., Beszczyńska-Möller A., Wieczorek P., Merchel M. \& Grynczel A. 2017. Oceanographic observations in the Nordic Sea and Fram Strait in 2016 under the IO PAN long-term monitoring program AREX. Oceanologia 59, 187-194, doi: 10.1016/j.oceano.2016.12.003.

Walczowski W. \& Piechura J. 2011. Influence of the West Spitsbergen Current on the local climate. International Journal of Climatology 31, 1088-1093, doi: 10.1002/joc.2338.

Wassmann P., Ratkova T., Andreassen I., Vernet M., Pedersen F. \& Rey F. 1999. Spring bloom development in the Marginal Ice Zone and the central Barents Sea. Marine Ecology 20, 321-346, doi: 10.1046/j.1439-0485.1999.2034081.x.

Weinkauf M., Kunze J., Waniek J. \& Kucera M. 2016. Seasonal variation in shell calcification of planktonic foraminifera in the NE Atlantic reveals species-specific response to temperature, productivity, and optimum growth conditions. PLoS One 11, e0148363, doi: 10.1371/journal.pone.0148363.

Werner K., Müller J., Husum K., Spielhagen R.F., Kandiano E.S. \& Polyak L. 2016. Holocene sea subsurface and surface water masses in the Fram Strait-comparisons of temperature and sea-ice reconstructions. Quaternary Science Reviews 147, 194-209, doi: 10.1016/j.quascirev.2015.09.007.

Werner K., Spielhagen R.F., Bauch D., Hass H.C., Kandiano E. \& Zamelczyk K. 2011. Atlantic Water advection to the eastern Fram Strait-multiproxy evidence for late Holocene variability. Palaeogeography, Palaeoclimatology, Palaeoecology 308, 264-276, doi: 10.1016/j.palaeo.2011.05.030.

Williams K.M. 1993. Ice sheet and ocean interactions, margin of the East Greenland ice sheet (14 Ka to present): diatom evidence. Paleoceanography 8, 69-83, doi: 10.1029/92PA02591.

Wollenburg J.E., Knies J. \& Mackensen A. 2004. High-resolution paleoproductivity fluctuations during the past 24 Kyr as indicated by benthic foraminifera in the marginal Arctic Ocean. Palaeogeography, Palaeoclimatology, Palaeoecology 204, 209-238, doi: 10.1016/S0031-0182(03)00726-0.

Van Aken H.M. 2006. The oceanic thermohaline circulation: an introduction. Dordrecht: Springer.

Vincent E. \& Berger W.H. 1981. Planktonic foraminifera and their use in paleoceanography. In C. Emiliani (ed.): The sea. Pp. 1025-1119. New York: Wiley Interscience.

Vinje T.E. 1977. Sea ice conditions in the European sector of the marginal seas of the Arctic, 1966-75. Norsk Polarinstitutt Årbok. 1975, 163-174.

Volkmann R. 2000. Planktic foraminifer ecology and stable isotope geochemistry in the Arctic Ocean: implications from water column and sediment surface studies for quantitative reconstructions of oceanic parameters. Berichte zur Polarforschung 361. Bremerhaven: Alfred Wegener Institute of Polar and Marine Research.

Volkmann R. \& Mensch M. 2001. Stable isotope composition $\left(\delta^{18} \mathrm{O}, \delta^{13} \mathrm{C}\right)$ of living planktic foraminifers in the outer Laptev Sea and the Fram Strait. Marine Micropaleontology 42, 163-188, doi: 10.1016/S0377-8398(01)00018-4.

Zamelczyk K., Rasmussen T., Husum K. \& Hald M. 2013. Marine calcium carbonate preservation vs. climate change over the last two millennia in the Fram Strait: implications for planktic foraminiferal paleostudies. Marine Micropaleontology 98, 14-27, doi: 10.1016/j.marmicro.2012.10.001. 